\title{
Estudo do satélite brasileiro Amazonia-1 E de sua trajetória: Mapeamento Sistemático e Análise Documental dos Artefatos Históricos - Oficiais
}

\author{
Study of the brazilian Amazonia-1 satellite and its trajectory: Systematic Mapping and \\ Documentary Analysis of Historical - Official Artifacts \\ Estudio del satélite brasileño Amazonia-1 y su trayectoria: Mapeo Sistemático y Análisis \\ Documental de Artefactos Históricos - Oficiales
}

Recebido: 18/01/2022 | Revisado: 22/01/2022 | Aceito: 24/01/2022 | Publicado: 25/01/2022

\author{
Wayrone Klaiton Luiz Silva \\ ORCID: https://orcid.org/0000-0001-8615-4382 \\ Instituto Federal de Educação, Ciência e Tecnologia Goiano, Brasil \\ E-mail: wayrone@gmail.com \\ Eliana Tiba Gomes Grande \\ ORCID: https://orcid.org/0000-0003-1155-6357 \\ Instituto Federal de Educação, Ciência e Tecnologia Goiano, Brasil \\ E-mail: eliana.tiba@ifgoiano.edu.br \\ Daniela Cabral de Oliveira \\ ORCID: https://orcid.org/0000-0002-9647-933X \\ Instituto Federal de Educação, Ciência e Tecnologia Goiano, Brasil \\ E-mail: danielacaboliveira@gmail.com
}

\begin{abstract}
Resumo
Este artigo apresenta e investiga as experiências da trajetória historiográfica da Missão Amazônia e, portanto, do desenvolvimento do Satélite AMAZONIA-1 em seus 41 Anos. Para isto, foi realizado um Mapeamento Sistemático (MS) para rastrear o estado da arte do Satélite, cujo resultado obteve-se apenas 7 referências acadêmicas. Após isto, realizou-se a Análise Documental (AD) ao coletar experiências e registros dos artefatos pela transcrição de vídeos presente na Plataforma Youtube, além de obter documentos oficiais do INPE, tendo em vista, desenvolver a evolução do quadro histórico e a análise das principais tecnologias satelitais sob etapas do ciclo de vida da missão. Com efeito, uma narrativa histórica foi construída para se utilizar, além de fontes históricas oficiais, da reunião de observações históricas, educacionais, econômicas e ambientais, sobretudo, tecnológicas. Parte-se da perspectiva de pesquisadores, tecnólogos, administradores, engenheiros e equipes, participantes e estudiosos da missão Amazônia. Como resultado, também, desenvolveu-se uma metodologia híbrida de $\mathrm{AD}$, que se ancora tanto de início no MS, quanto no decorrer do trabalho na pesquisa bibliográfica. Pôde-se, ainda, fomentar o debate sobre desenvolvimento satelital, fornecendo: i) importantes apontamentos educacionais, ambientais e econômicos; ii) embasamento dos aspectos conceituais-práticos da missão espacial; iii) a formulação da definição do projeto preliminar e; iv) a Missão Amazônia em suas experiências históricas e factuais (2001-2021) de otimização, transferência tecnológica, implementação e lançamento.
\end{abstract}

Palavras-chave: Educação espacial; História; Tecnologia; Espaço; Brasil.

\begin{abstract}
This study presents and investigates the experiences of the historiographical trajectory of the Amazônia Mission and, therefore, of the development of the AMAZONIA-1 Satellite in its 41 years. For this, a Systematic Mapping (SM) was carried out to track the state of the art of the Satellite whose result was obtained only 7 academic references. After that, the Document Analysis (DA) was carried out by collecting experiences and records of artifacts through the transcription of videos present on the Youtube Platform. In addition to obtaining official documents from INPE, in order to develop the evolution of the historical framework and the analysis of the main satellite technologies under stages of the mission life cycle. Indeed, a historical narrative was built to use, in addition to official historical sources, the gathering of historical, educational, economic and environmental observations, especially technological. It starts from the perspective of researchers, technologists, administrators, engineers and teams, participants and scholars of the Amazon mission. As a result, a hybrid AD methodology was also developed, which is anchored, both initially in the MS, and in the course of the work in the bibliographic research. It was also possible to foster the debate on satellite development, providing: i) important appointments educational, environmental and economic notes; ii) foundation of the conceptualpractical aspects of the space mission; iii) the formulation of the preliminary project definition and; iv) the Amazon Mission in its historical and factual experiences (2001-2021) of optimization, technology transfer, implementation and launch of the artifact.
\end{abstract}


Keywords: Space education; History; Technology; Space; Brazil.

\section{Resumen}

Este artículo presenta y explora las experiencias de la trayectoria historiográfica de la Misión Amazonía y, por tanto, del desarrollo del Satélite AMAZONIA-1 en sus 41 años. Para ello se realizó un mapeo sistemático para rastrear el estado del arte del Satélite, de cuyo resultado se obtuvo únicamente 6 referencias. Posteriormente, se relevaron experiencias y artefactos históricos mediante la transcripción de videos presentes en la Plataforma Youtube, además de obtener documentos oficiales del INPE, con el fin de desarrollar la evolución del marco histórico y el análisis de las principales tecnologías satelitales en etapas de desarrollo el ciclo de vida de la empresa misión. Las prácticas metodológicas aquí tipificadas son Mapeo Sistemático (MS) y Análisis de Documentos (AD). En efecto, se construyó una narrativa histórica para utilizar, además de las fuentes históricas oficiales, la recopilación de observaciones educativas, económicas y ambientales, especialmente tecnológicas. Se parte de la perspectiva de investigadores, ingenieros, tecnólogos, administradores y equipos, participantes y estudiosos de la misión Amazonía. Como resultado, fue posible incentivar el debate sobre el desarrollo de satélites, aportando: i) importantes notas educativas, ambientales y económicas; ii) fundamentación de los aspectos conceptuales-prácticos de la misión espacial; iii) la formulación de la definición preliminar del proyecto (1980-2000) y; iv) la Misión Amazonía en sus experiencias históricas (2001-2021) de optimización, fabricación, transferencia de tecnología, implementación y lanzamiento.

Palabras clave: Educación espacial; Historia; Tecnología; Espacio; Brasil.

\section{Introdução}

Em 41 anos de desenvolvimento, referindo-se ao planejamento e implementação, o Satélite Amazonia-1 foi construído sob fruto de esforço e aprendizado histórico de pesquisadores, tecnólogos, administradores e equipes dedicadas, em conjunto, ao fortalecimento do Setor Espacial Brasileiro; fato que insere o Brasil no grupo seleto de desenvolvedores satelitais. Em retrospectiva, nas palavras de Moura et al. (2021 $)$ e Genaro et al. $\left(2021^{2}\right)$, a Missão Amazônia é mais do que um Satélite, de desenhos em décadas sob um contexto de apenas tecnologias pagas ou feitas em parceria evoluiu-se para o artefato lançado em plena pandemia na Índia.

Em 2021, a primeira versão do projeto foi iniciada em 1980, em que o projeto se denominava "Satélite de Sensoriamento Remoto Óptico (SSR ${ }^{3}$ )", e que se obteve, em suas duas primeiras versões, os nomes de SSR-1 e SSR-2, pela Agência Espacial Brasileira (AEB) e para Missão Espacial Completa Brasileira (MECB) (Costa, 2002). O SSR desde sua criação, futuramente Amazonia-1, herdou da missão MECB as preocupações de estabelecer competências educacionais e tecnológicas no país para qualificar a indústria nacional; a necessidade de execução do ciclo do programa espacial completo; assim como a demanda de proteção ambiental e desenvolvimento tecnológico pelo uso do sensoriamento remoto para fins de acompanhamento da região amazônica.

Após o ano 2000, com o início da construção das primeiras Plataformas Multimissão (PMM) do SSR, o satélite em sua terceira versão foi renomeado de Amazonia, e, depois, finalmente, para o nome atual, Amazonia-1. A nomenclatura técnica dada como título ao satélite, sem o acento, reforça o foco inicial da missão, que é disponibilizar dados de imagens para o sensoriamento remoto óptico ${ }^{4}$, a partir do monitoramento do território brasileiro, especialmente para região amazônica (Breternitz ${ }^{5}$ S Silva, 2021). Conforme Pontes $\left(2021^{6}\right)$, assim, o Amazonia-1, também, foi projetado com uma finalidade ambiental, para monitoramento e mapeamento da região amazônica, ao complementar a constelação de Satélites Sino-Brasileiros de Recursos Terrestres (CBERS), o 4 e o $4 \mathrm{a}$, além de se somar a outros satélites nacionais ou internacionais. Por esta característica complementar, o artefato contribui com a precisão das imagens e maior taxa de revisita, de modo que fornece geoinformação

\footnotetext{
${ }^{1}$ Informação concedida para o período na entrevista de Marcos Chamon, Coordenador de Planejamento e Monitoramento - INPE, ao canal MundoGEO.

${ }^{2}$ Informação concedida para o período na entrevista de Adenilson Roberto da Silva, doutor em Engenharia e Tecnologia Espaciais pelo INPE e gerente do Amazonia-1, no vídeo do canal Inpemct.

${ }^{3}$ A maioria das siglas deste trabalho estão em português, exceto as que forem mencionadas na própria sigla.

${ }^{4}$ Atua na área visível, porque a visualização não ultrapassa as nuvens em cima da superfície terrestre.

${ }^{5}$ Informação concedida no período a Revista Pesquisa FAPESP na entrevista de Vivaldo José Breternitz, especialista no setor aeroespacial, da Universidade Presbiteriana Mackenzie, de São Paulo.

${ }^{6}$ Informação concedida para o período na entrevista de Marcos Cesar Pontes, foi o primeiro astronauta brasileiro a ir no espaço e atual Ministro da Ciência, Tecnologia e Inovações - INPE, ao canal RedeTV.
} 
adequada para tomada de decisão das tropas de solo, dentre outras aplicações.

A partir de 2002, para o quesito educacional os projetos de Transferência ${ }^{7}$ de Tecnologia Espacial (ToT) foram iniciados para o Amazonia-1, onde foi destinado cerca de $60 \%$ dos recursos orçamentários para o firmamento de contratos com a indústria brasileira, com vistas a promover a transferência tecnológica para 10 empresas participantes ${ }^{8}$ da missão. Uma de suas bases legais, é o Decreto n 1332, de 08/12/1994, em que a diretriz da Política Nacional de Desenvolvimento das Atividades Espaciais (PNDAE) dentre as demandas centrais, orienta a capacitação educacional brasileira no setor espacial e incentiva a participação em tecnologias industriais estratégicas (INPE, 2021). No conteúdo desta Lei, foi determinado:

A participação da indústria nacional nos programas de desenvolvimento de tecnologias e sistemas espaciais é condição necessária para a efetiva absorção pelo setor produtivo da capacitação [...], devendo-se: i) promover a qualificação da indústria nacional não apenas para o fornecimento de partes e equipamentos, mas, também, para o desenvolvimento e a manufatura de subsistemas e sistemas completos; ii) buscar a integração entre as equipes das instituições de pesquisa, desenvolvimento e os seus parceiros industriais, através da realização conjunta de projetos de desenvolvimento tecnológico que incluam a indústria desde a etapa de concepção [...]. Os projetos de capacitação em novas tecnologias deverão priorizar o domínio de tecnologias consideradas estratégicas para o País, segundo critérios que incluam: importância para sistemas ou serviços espaciais de grande interesse para o País; dificuldades de importação existentes no âmbito internacional; obter potencial valor comercial dessas tecnologias para empresas brasileiras; e competências e facilidades disponíveis no País, que permitam aspirar a contribuições inovadoras ao estado da arte (Brasil, 1994, p.4).

Como é possível visualizar no conteúdo jurídico da Lei, houve preocupações no sentido de promover os parceiros industriais para fortalecer a indústria espacial brasileira. Porém, no caso do Satélite Amazonia-1 não se teve o objetivo exclusivo de atender os diferenciais globais de inovação e para competir comercialmente no mercado internacional de satélites. A produção desta tecnologia, além obviamente de aprimorar continuamente os dispositivos espaciais, teve o objetivo de fomentar o desenvolvimento da autonomia tecnológica do Setor Espacial Brasileiro, para fortalecer o aprendizado tecnológico do INPE e das 10 empresas participantes da missão (Kaufmann ${ }^{9} \&$ Silva, 2016; Breternitz ${ }^{10} \&$ Silva, 2021).

Então, a Missão Amazônia visa alcançar também maior nível de educação espacial na medida que propiciar experiências tecnológicas de fabricação de satélites, além de transferência e aprendizado tecnológico no setor industrial e acadêmico. Por exemplo, conforme Moura et al. (2021 ${ }^{11}$ ) foram fabricadas tecnologias brasileiras de Subsistema de Propulsão, Caixa-Preta (que contém a gravadora de imagens e áudio), Subsistema de Painéis Solares, Antena Transmissora de Dados, Subsistema Câmera ${ }^{12}$ Wide Field Imager (WFI), Câmera Imageadora de Amplo Campo de Visada, entre outros componentes, que em conjunto, correspondem a um percentual de produção ${ }^{13}$ brasileiro entre $70 \%-80 \%$ do Satélite; fator que estimula a formação de competências educacionais e tecnológicas nos participantes.

Pela herança da MECB, a missão Amazonia-1 em sua trajetória deveria atender um escopo amplo de demandas da

\footnotetext{
${ }^{7}$ É o termo utilizado para decisão de empresas e de profissionais em transferir conhecimento industrial, suas fórmulas e experiências, para construção de elementos espaciais, sejam o veículo lançador, ou então satélites. Atualmente, também há o termo absorção tecnológica, diferente da ToT, para se referir aos indivíduos treinados junto às empresas. Disponível em: <https://www.gov.br/aeb/pt-br/assuntos/noticias/aeb-explica-entenda-conceitos-e-praticas-datransferencia-de-tecnologia>. Acesso em: 01/11/2021.

${ }^{8}$ Segundo o INPE (2021), quanto à participação da indústria espacial brasileira, houveram contratos com empresas responsáveis pelo desenvolvimento dos Subsistemas PMM e do Módulo de Carga Útil. No Módulo de Serviço (PMM), a CENIC Engenharia Indústria e Comércio Ltda. foi contratada para criação da Estrutura do Módulo de Serviço; ORBITAL para criação da Engenharia do Gerador Solar e; Fibraforte Engenharia Indústria Comércio para criação da Propulsão. No Módulo de Carga Útil, CENIC foi contratada também para criação da Estrutura do Módulo Carga Útil; a Opto Eletrônica para Câmera AWFI; Omnisys Engenharia Ltda. para Antena Banda X do AWDT; Equatorial Sistemas para Gravador Digital de Dados, Omnisys Engenharia Ltda. para RTU e; o AEL Sistemas para DC/DC. INPE. Disponível em: http://www.inpe.br/amazonia1/industria_nacional.php. Acesso em: 01/11/2021.

${ }^{9}$ Informação concedida no período a Revista Pesquisa FAPESP na entrevista de Pierre Kaufmann, professor da Escola de Engenharia da Universidade Presbiteriana Mackenzie e coordenador do Centro de Rádio-Astronomia e Astrofísica Mackenzie.

${ }^{10}$ Informação concedida no período a Revista Pesquisa FAPESP na entrevista de Vivaldo José Breternitz, especialista no setor aeroespacial, da Universidade Presbiteriana Mackenzie, de São Paulo.

${ }^{11}$ Informação concedida para o período na entrevista de Marcos Chamon, Coordenador de Planejamento e Monitoramento - INPE, ao canal MundoGEO.

${ }^{12}$ Outrossim, o novo dispositivo Advanced Wide Field Imager - AWFI.

${ }^{13}$ No quesito produtivo, têm se observado que os produtos eletrônicos, o tanque de hidrazina e alguns outros, foram importados por causa do menor custo e de não ser viável a fabricação brasileira. Esta limitação produtiva foi justificada neste caso, pois nenhum país é absolutamente auto suficiente na construção de satélites. Por exemplo, os EUA e a China têm fabricado praticamente a maioria de suas tecnologias espaciais, exceto alguns equipamentos, que sugerem a mesma explicação, afirma Moura et al. (2021).
} 
sociedade, sejam educacionais, ambientais e econômicas, sobretudo tecnológicas, necessárias ao seu desenvolvimento tecnológico e evolução histórica.

Assim, este artigo tem por objetivo retratar o trajeto percorrido do Satélite Amazonia-1 em seus 41 anos de desenvolvimento. Para investigar as experiências, fatos e artefatos presentes na trajetória historiográfica da Missão Amazônia, realizou-se a análise das tecnologias satelitais sob etapas do ciclo de vida da missão, bem como a descrição da evolução do quadro histórico. A metodologia utilizada foi o Mapeamento Sistemático (MS) e a Análise Documental (AD).

\section{Metodologia}

Agregou-se confiabilidade ao processo de busca por referências e maior relevância a pesquisa ao adotar a metodologia de Mapeamento Sistemático (MS) no início da pesquisa. Petersen et al. (2008) afirmam que a primeira etapa é demarcar a questão da pesquisa. Assim, a pergunta foi definida: "Quais estudos existentes sobre Satélite Amazonia-1 poderiam subsidiar uma revisão bibliográfica ou análise, a incluir várias áreas de conhecimento?". De fato, a intenção de se utilizar o MS foi para identificar pesquisas sobre o Satélite Amazônia-1 desde 1980, data próxima da idealização do SSR, para entendê-lo desde o início de sua concepção.

Para estes autores (2008), as etapas seguem uma sequência objetiva e assertiva: selecionar pesquisas e conteúdos relevantes por meio de critérios de inclusão e exclusão; classificar por meio de resumos e títulos; e por último; extrair dados. Sem haver critérios para exclusão inicialmente, uma string foi definida para busca de estudos variados que tivessem os termos "Satélite (ou Satellite) Amazonia-1". Nos locais de busca foram definidos 8 (oito) bancos de fontes bibliográficas selecionadas do meio acadêmico, a abranger: Google Acadêmico, Banco Nacional de Teses e Dissertações, SciELO, Periódicos Capes, ArXiv, Biblioteca Digital da Câmara dos Deputados, Arca e INPE. Ao final do processo, foram averiguados resumos e palavras-chave, bem como lidos os contextos e períodos que constam na introdução, metodologia e conclusão dos trabalhos, sendo observado a relevância desses conteúdos, em suas respectivas áreas do conhecimento.

Sob tais critérios metodológicos, a busca encontrou apenas 7 (sete) conteúdos com termo específico definido para responder à questão da pesquisa. A escassez de estudos acadêmicos sobre o satélite Amazonia-1 pode ser em parte justificada quanto ao lançamento por ser um evento recente. Também há de se concordar que por se tratar de um conhecimento estratégico existe uma preocupação com a proteção de tal saber tecnológico da área espacial. Porém, isto não explica totalmente o baixo número de referenciais, ainda mais se considerarmos que o desenvolvimento deste tem perpassado décadas. Relativo as áreas de conhecimento, obteve-se o seguinte resultado: Engenharia de Sistemas (1 trabalho); Mecânica Espacial e Controle (3 trabalhos), bem como o Eixo Histórico-Geográfico-Econômico (3 trabalhos). Esta avaliação que foi descrita corrobora com a hipótese de que há demanda por estudos sobre este satélite em várias áreas de conhecimento. Paralelamente, na plataforma do INPE obtevese o retorno da busca com 590 resultados de fontes, composto por notícias de jornais, imagens e vídeos. Em outras palavras, uma maior quantidade de fontes documentais e históricas de acesso público foram encontradas, o que demostra a disponibilidade de tais conteúdos para pesquisa.

Assim, o MS foi importante para identificar essa lacuna no estado da arte do Satélite Amazonia-1 e direcionou para adotarmos a Pesquisa Documental (PD) como metodologia de análise. Historicamente, a PD tem papel-chave na construção de conhecimentos, sobretudo quando analisamos cenários complexos e alteráveis como o desenvolvimento histórico de uma tecnologia espacial por décadas de implementação. Conforme Scorsolini-Comin (2021), as pesquisas documentais recorrem as fontes primárias, materiais que não receberam tratamento analítico e requerem uma análise mais cuidadosa, além de possibilitar a descrição, especificação e monitoramento de informações no decorrer do tempo para ampliar a compreensão dos efeitos e transformações de um dado fenômeno. Ao mesmo que, em alguns casos, têm-se dificuldades para apresentar evidências práticas 
em níveis altamente rigorosos. O método fornece ainda a possibilidade de explorar reflexões e construir narrativas, sob subsídio de técnicas descritivas ou tendo base na pesquisa bibliográfica.

No contexto da pesquisa, coletamos informações junto ao Sistema de Acesso à Informação - Web Fala.BR. A documentação da câmera WFI foi fornecida pelo INPE (2018). No escopo documental, ainda foi incluído 6 (seis) entrevistas obtidas de reportagens escritas, e que continham a transcrição das falas de participantes e estudiosos da Missão Amazônia, dentre os quais, são: Breternitz e Silva (2021), Câmara (2012), Castro Neto (2021), Galvão (2021), Kaufmann e Silva (2016) e Silva et al. (2019).

Dado o caráter insuficiente de fontes bibliográficas, empregamos também, informações audiovisuais disponíveis nas plataformas públicas. Para alguns casos, a análise dos vídeos requereria a transcrição literal da fala dos depoentes pelas normas da história oral. No caso dessa pesquisa, o ato de transcrição literal dos aspectos orais quanto ao conteúdo videográfico, por sua atividade extensa, tornaria improdutivo o desenvolvimento deste trabalho. Portanto, optou-se pela não transcrição da fala dos depoentes ao utilizar-se do recurso Ipsis Litteris (não literal) e na análise das referidas fontes foi considerado tanto as legendas automaticamente geradas pela plataforma, quanto a checagem perceptiva dessa mídia.

Este trabalho demanda, ainda, responsabilidade ética, além de uma investigação paralela para confirmação e checagem de fatos históricos e informações citadas. Ressalta-se, então, que interpretar a transcrição obtida implica na escolha da atuação intelectual do pesquisador e no próprio exercício de integridade (Amado, 1997).

Ademais, o tópico da presente pesquisa aborda um conhecimento estratégico para o país. As informações adquiridas são de interesse social e de finalidade educacional. Portanto, não são protegidas no âmbito da segurança nacional pela Lei de Acesso à Informação (n 12.527/2011). A Resolução no 510/2016 do Conselho Nacional de Saúde (CNS) junto à Lei citada anteriormente dispensa a apreciação do Comitê de Ética em produções científicas que se utilizam de conteúdos de domínio público. Sendo considerado como tal, os vídeos, entrevistas transcritas e documentos oficiais divulgados com o fim de disseminação do conhecimento público, desde que trate de informações pessoais "de forma transparente e com respeito", têm estes conteúdos livre acesso e reprodução.

A transcrição ou o vídeo em seu conteúdo proposto deve ser interpretado sob alto domínio dos fatos, e de acordo com a padronização da norma culta, considerando a intenção do depoente no contexto videográfico. Além do mais, o dado deve ser reproduzido de forma neutra, e ao mesmo tempo, alinhando-se com os elementos teóricos presente no objeto, sem prejuízo a caracterização e intenção da autoria falante (Silva et al., 2014).

Nos meses entre junho a agosto de 2021 o Mapeamento Sistemático (MS) foi realizado novamente com vistas a seleção dos conteúdos videográficos que utilizassem a palavra-chave "Satélite Amazonia-1" no filtro de busca da plataforma YouTube, e sem delimitar restrições. A seleção inicial se pautou na escolha de vídeos de cunho informativo e educacional, contendo depoimentos, reportagens, debates e entrevistas de participantes ou estudiosos da Missão Amazônia. No total, 25 vídeos públicos foram coletados inicialmente, considerando-os como documento no formato audiovisual. Para cada vídeo disponível pela plataforma, a transcrição automática do Youtube também era disponibilizada pela ferramenta de transcrição do Youtube.

No processo de coleta, os 15 vídeos excluídos não obtiveram experiências significativas para o estudo; e somente 10 vídeos foram selecionados para serem assistidos e analisados na íntegra, dentre os quais, são: Genaro et al. (2021), Moura (2021), Nardin (2021), Nogueira e Barbosa (2021), Pontes (2021), Santos et al. (2021), Silva (2021), Silva (2021), Silva et al. (2021) e Venticinque (2021). A Análise Documental (AD) dessas referidas fontes permitiu a extração e tratamento das informações, de forma que o conteúdo e a intencionalidade das transcrições e falas foram averiguadas; bem como as telas dos conteúdos videográficos foram capturadas como provas documentais. 


\section{Resultados e Discussão}

\subsection{Desenvolvimento Satelital: Apontamentos educacionais, ambientais e econômicos}

Se na atualidade, as ondas elétricas podem ser recebidas pelas emissoras de TV, e se tem notícias que correm o mundo a tempo e a hora, seja por internet ou ligações telefônicas, e também se tem o monitoramento dos ambientes terrestres com imagens da previsão do tempo com precisão e qualidade. Além do envio da informação se dar em qualquer localidade terrestre ou destinar-se aos confins do universo. Este funcionamento se deve, primeiro, ao lançamento de satélites nas órbitas terrestres e ao desenvolvimento de tecnologias espaciais. Pela alta demanda e, devido à busca do estado da arte no desenvolvimento tecnológico, tornou-se um setor lucrativo, porém que necessita de altos investimentos, sendo poucos países que possuem domínio técnico, comercial e educacional no setor (Epiphanio, 2003).

Ademais, o desenvolvimento do conhecimento para acesso direto ao espaço exterior do planeta Terra e o domínio das tecnologias necessárias no âmbito espacial para realizar tal feito, se estabeleceram como um farol para impulsionar e consolidar o avanço estratégico do setor de Ciência, Tecnologia e Inovação (CT\&I) no mundo; quer como uma vantagem geopolítica dos países para manter o poderio militar e a soberania dos territórios ocupados e nacionais; quer como vantagem econômica para assegurar o desenvolvimento e a competitividade (Viegas \& Santos, 2020).

A despesa do custo de funcionamento do satélite pode ser transformada em receita futura; por exemplo, a coleta e a análise de informações de objetos terrestres servem para diagnosticar períodos climáticos para colheita, desmatamento ilegais e outras finalidades. Portanto, o investimento na atividade espacial deve colaborar com a melhora da qualidade de vida de um país, seja pela intervenção do Estado, pela iniciativa privada ou pela qualidade da atuação de atores técnicos do Setor Espacial Brasileiro (Pereira, 2008; Viegas \& Santos, 2018).

Neste quesito ambiental, há desafios que assumem uma importância urgente, crescente e sem precedentes que, por sua vez, impactam na área social e econômica dos países. Ocorre de maneira particular no Brasil que subsiste na maior parte do setor primário e nas últimas décadas vem gerando demandas no setor tecnológico espacial. Ao acolher esta demanda urgente, os satélites de monitoramento são geotecnologias úteis para apoiar a formulação de diretrizes de planejamento e de conservação ambiental, aliando-se ao monitoramento da restauração florestal. A atuação conjunta de satélites de monitoramento, de forma a sincronizar seus sistemas de alta tecnologia e de sensores remotos orbitais, além do fomento para democratizar tal conhecimento ambiental, tem contribuído para disseminação de informações geoespaciais, bem como desenvolvimento de aplicações diversas e multidisciplinares nos campos científicos, o que impacta positivamente na sociedade e economia (Escada, 2021).

O Brasil se tornou uma referência para o desenvolvimento e uso de sistemas de monitoramento e mapeamento de uso/cobertura da terra, especialmente florestas por meio de tecnologias aprimoradas de Geoprocessamento, Sensoriamento Remoto e Sistemas de Informação Geográfica (SIG), portanto, Geotecnologias ${ }^{14}$. Para se obter êxito, as decisões ambientais foram tomadas amparadas nesses dados dos satélites, nas análises e interpretações de especialistas referente às imagens satelitais, e por último, na aplicação e desenvolvimento de algoritmos para interpretação das imagens (Escada, 2008).

Deste modo, o efeito destas transformações sociais, técnicas, ambientais e econômicas ocasionadas pelo setor espacial propiciou a melhoria da qualidade de vida da humanidade. Assim, a importância do setor espacial, e de seu desenvolvimento satelital, deve abranger também a países com menor desenvolvimento econômico como o Brasil, tendo em vista, que se transfira, absorva e se apreenda o conhecimento tecnológico para promover-se a educação espacial e proteção ambiental; fato importante para o Brasil alcançar sua própria autossuficiência, e imprescindível para promoção do desenvolvimento socioeconômico dos

\footnotetext{
${ }^{14} \mathrm{O}$ geoprocessamento capta, armazena, trata e processa as imagens geográficas ou georreferenciadas pelo uso de técnicas, métodos teórico-matemáticos e computacionais. O sistema de informação geográfica (SIG) possibilita a análise, gestão ou representação do espaço e de seus fenômenos. O sensoriamento remoto é a detecção remota via sensores do satélite que mensura o registro da interação da radiação eletromagnética e a obtenção de informações dos alvos terrestres (Silva et al. 2006).
} 
países, sobretudo, dos menos desenvolvidos. Este estímulo deve ocorrer, além da vantagem geopolítica e econômica, mas para qualidade de vida dos cidadãos (Pereira, 2008).

Santos (2010) afirma que no Brasil, o desenvolvimento do setor espacial não acompanhou o mesmo ritmo de sua indústria da aviação, devido a necessidade de investimentos privados, governamentais, de planejamento estratégico, assim como pela ausência de capital humano qualificado, entre outras causas. Alguns países emergentes, como a Índia, Coreia do Sul e a China possuem um setor espacial coerente com a participação das empresas, laboratórios atualizados e uma alta qualificação em recursos humanos. De fato, a indústria espacial está interligada com os demais setores de desenvolvimento tecnológico do país, e deve ser amparada pelo sólido setor aeronáutico brasileiro e de seus conhecimentos aplicados no ramo de sensoriamento remoto visando o fortalecimento da indústria espacial.

Por sua vez, Sausen (2009) afirma que no território brasileiro, embora sua colocação seja a melhor no ranking de países latino-americanos no setor espacial, nos últimos anos tem se necessitado da obtenção de maior qualificação de mão de obra espacial e o aumento produtivo de novos ativos intelectuais. Para isto, a educação espacial deve disseminar, produzir e aplicar conhecimento do Setor Espacial Brasileiro por meio da criação e vivência de ambientes de aprendizado, seja laboratórios, iniciativas espaciais e experiências positivas no cotidiano comum. O preparo das novas gerações deve ocorrer para substituição dos profissionais do setor que irão se aposentar, o que é possível ao motivar interessados a entrarem na área espacial; fornecendo adequada, ampla e contínua capacitação educacional para a área.

De fato, as experiências de promoção a educação espacial a docentes, discentes e a empresas pode ocorrer a partir do contato com estudos conceituais-práticos, experimentos de peças de satélites e na participação em iniciativas satelitais reais, dentre outros (Reis et al. 2008). Segundo INPE $(2021)^{15}$, nos editais de contratação para transferência tecnológica, o objetivo é ensinar as empresas brasileiras a obterem autonomia no desenvolvimento dos próprios projetos de tecnologias espaciais.

Sendo assim, o desenvolvimento satelital tem sido justificado como elemento estratégico, e possível, pelo incentivo do setor de CT\&I dos países, e pelo seu retorno social, econômico, ambiental e para fomento da educação espacial; sendo esta última no sentido de assegurar qualificação técnica e o futuro do setor. De fato, dentre os instrumentos educacionais e produtivos existentes no INPE, a atividade de Transferência Tecnológica Espacial tem sido necessária.

\subsection{Missão Espacial: Aspectos conceituais-práticos}

Os sistemas satelitais como Amazonia-1, são artefatos que possuem uma estrutura de médio porte por suportar a capacidade de carga total de 2 mil a $1800 \mathrm{~kg}$ a altitudes entre 600 e $900 \mathrm{~km}$ e com alta complexidade em desenvolvimento (Kaufmann ${ }^{16} \&$ Silva, 2016). Segundo Ley et al. (2009), tal complexidade demanda elevado custo produtivo, equipes altamente treinadas com rápida curva de aprendizado, comunicativas e multidisciplinares, atuantes em conjunto e individualmente, para atender as necessidades dos stakeholders, os usuários.

No campo da engenharia aeroespacial, Wertz e Larson (2011) sugerem que o conceito de missão é a especificação dos elementos envolvidos e de suas relações técnicas para atingir o objetivo. A missão espacial que se quer produtiva e funcional deve ter guias para formular um sistema espacial, abordando em resumo: 1) Objetivos gerais e específicos; 2) Conceito e arquitetura da missão; 3) Conceito da operação; 4) Viabilidade; 5) Segmentos (espacial, solo e lançamento); 6) Elementos espaciais; 7) Função do projeto; 8) Requisitos; 9) Restrições; 10) Custo; 11) Risco e; 12) Cronograma.

Na Figura 1 é ilustrado os elementos teóricos da missão espacial, em que aborda o conceito e a arquitetura de missão. Conforme Ley et al. (2009), os elementos espaciais de uma missão são divididos para alcançar seus objetivos, tais como: i)

\footnotetext{
${ }^{15}$ Disponível em: http http://www.inpe.br/pci/arquivos/Edital_27_2021_v_02.pdf. Acesso em: 01/11/2021.

${ }^{16}$ Informação concedida no período a Revista Pesquisa FAPESP na entrevista de Pierre Kaufmann, professor da Escola de Engenharia da Universidade Presbiteriana Mackenzie e coordenador do Centro de Rádio-Astronomia e Astrofísica Mackenzie.
} 
Controle da missão e centro de operação da missão; ii) Estações terrestres; iii) Conceito da missão; iv) Elemento espacial (satélites); v) Processamento, arquivamento e distribuição de dados; vi) Usuários; vii) Órbita e ambiente espacial; viii) Veículo lançador e; ix) Arquitetura de comunicação.

Figura 1: Elementos Teóricos da Missão Espacial.

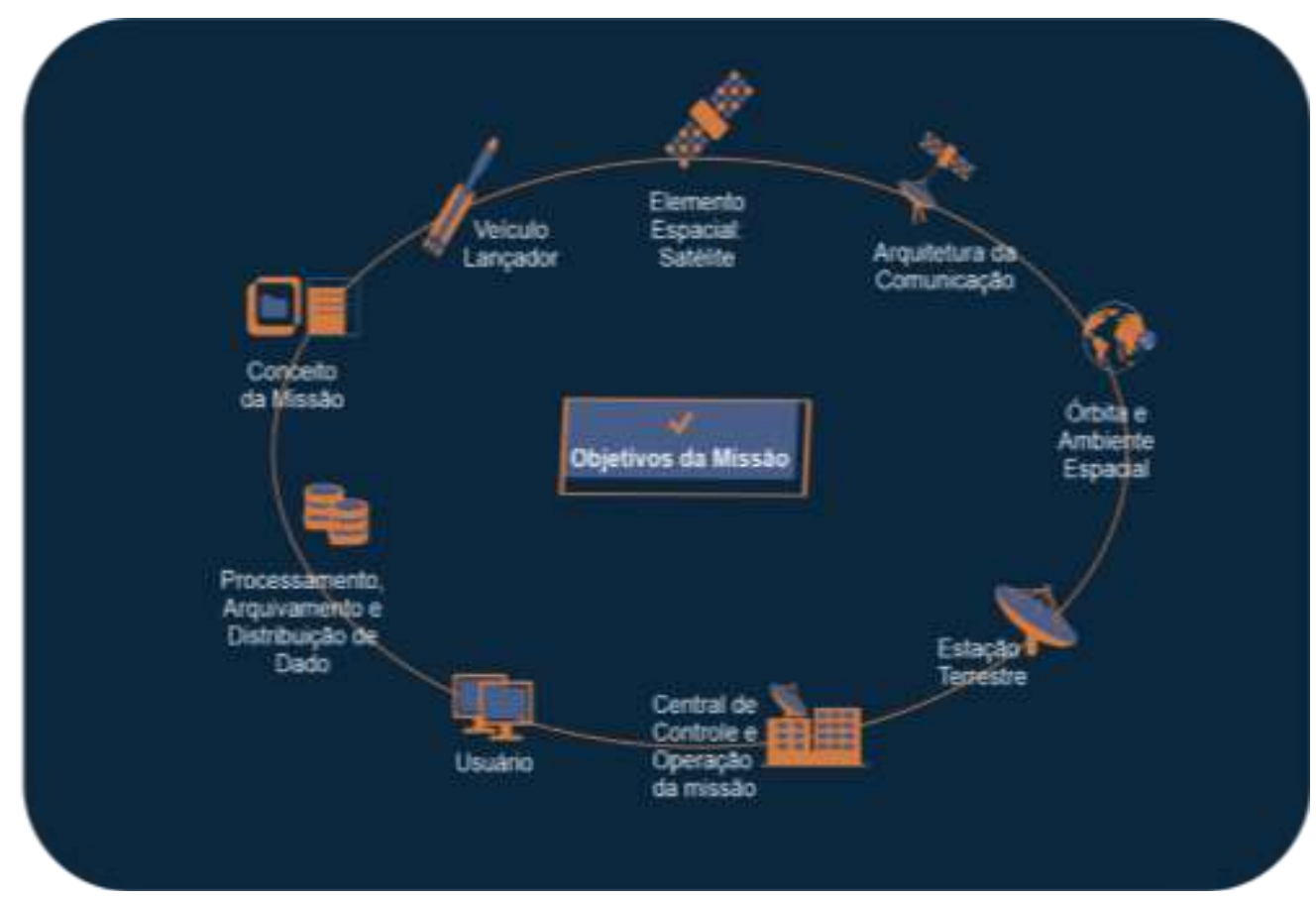

Fonte: Adaptado de Wertz e Larson (2011) e Ley et al. (2009) pelos autores.

Com base na Figura 1, para que o satélite seja colocado em órbita, no local, na posição e na velocidade adequada, necessita-se da execução do ciclo de vida do projeto. Para isto, deve-se ocorrer a organização dos elementos da missão, bem como execução do processo de planejamento e desenvolvimento dos elementos espaciais, no caso, o artefato satelital.

De acordo com Epiphanio (2003), o satélite é lançado no centro de lançamento pelo veículo lançador, em uma órbita provisória para ser transferido a uma órbita selecionada para missão. A comunicação deve ser obtida e arquitetada pelas estações terrestres e pelas centrais de controle. No espaço, os sensores remotos projetados devem captar os dados ${ }^{17}$ da superfície terrestre e da órbita terrestre e, enviá-los para as centrais de controle, processando tal informação. A partir disso, são distribuídas para as estações terrestres no segmento solo e depois para usuários com finalidades diversas. No momento que for desativado, o satélite é direcionado para uma órbita inativa.

No quesito órbita e ambiente espacial, os satélites artificiais e naturais agem sob a força de atração gravitacional. Os satélites artificiais são feitos para serem lançados na órbita de um planeta, enquanto os satélites naturais são planetas que orbitam no entorno de uma estrela. Por exemplo, o satélite Lua gira no entorno do planeta Terra. Os satélites artificiais geralmente trabalham em conjunto em uma constelação de satélites para obter melhor resolução sobre o alvo terrestre (Epiphanio, 2003; Ley et al. 2009).

O ambiente espacial apresenta efeitos de alta periculosidade e dano físico ao artefato espacial, como ilustrado na Figura 2. As estruturas do satélite no espaço são expostas a fatores como temperaturas extremas, efeito gravitacional e ciclagem térmica. Por isto, os materiais em altas temperaturas perdem suas propriedades mecânicas, enquanto que nas baixas, tornam-se frágeis.

\footnotetext{
${ }^{17}$ Dados de comunicação, imagens de observação da terra, informações de navegação, posicionamento orbital, meteorologia, ciência, defesa e desenvolvimento tecnológico (Epiphanio, 2003).
} 
Entre as características observadas, as partículas de explosões solares geram interferências; as partículas de cinturão de radiação provocam degradação e danos radioativos e determinados tipos de materiais podem ser corroídos pelo oxigênio atômico presente na atmosfera residual, e outros (Bussu, 2008).

Figura 2: Riscos perigosos para os artefatos espaciais.

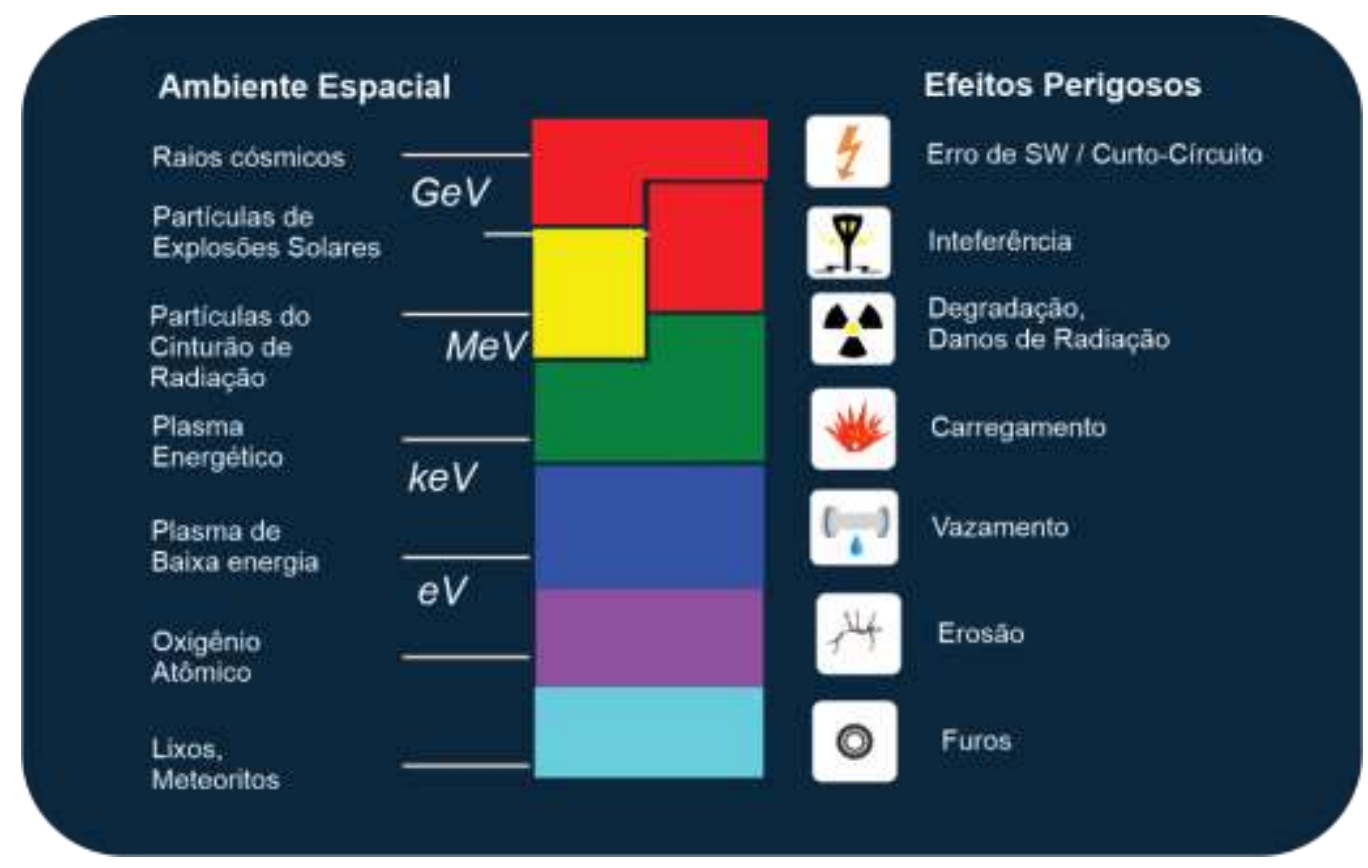

Fonte: Adaptado de Bussu (2008) pelos autores

Aplicando o conceito de missão espacial no tocante à base de operações solo do Satélite Amazonia-1 no território brasileiro na Figura 3 a seguir, observa-se que os Sistemas de Antena de Rastreio (SAR) estão instalados em Cuiabá e Alcântara. As estações terrenas de rastreio são o Centro de Controle de Satélites (CCS), em São José dos Campos, SP; bem como Estação Terrena de Rastreio e Controle (ETRC), em Alcântara, MA; e a Estação Terrena de Rastreio e Controle (ETRC), em Cuiabá, MT. Na representação, o CCS recebe dados, e ao mesmo tempo, envia telecomandos; as demais estações terrenas recepcionam e transmitem os dados aos satélites controlados por meio do SAR. 


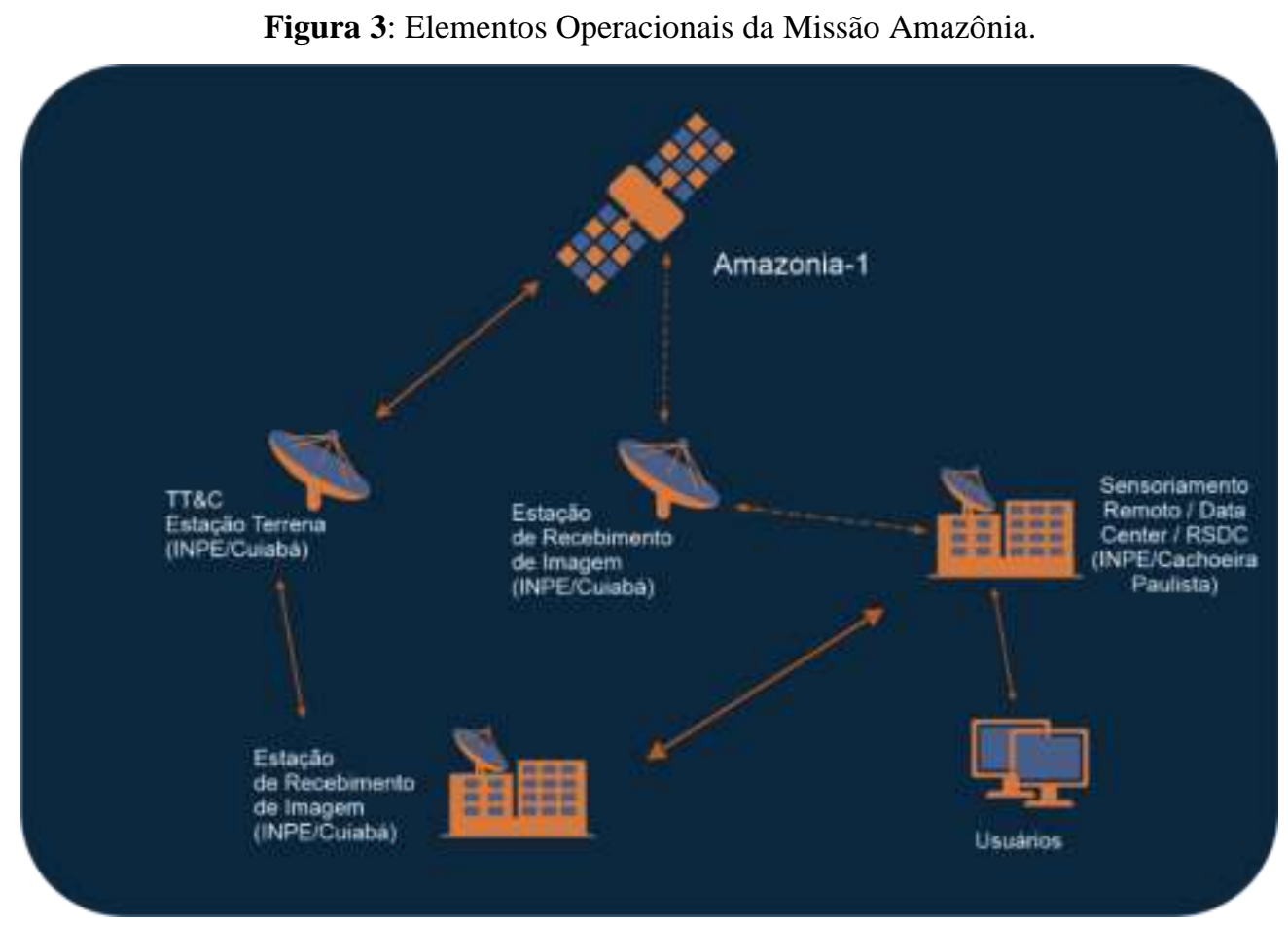

Fonte: Adaptada de INPE $(2021)^{18}$.

Em um projeto satelital, a definição do objetivo comercial da missão deve ser diferenciada do acadêmico. Enquanto, que o primeiro incorpora a necessidade de mercado, a seguinte objetiva a capacitação educacional e científica da equipe envolvida. Assim, para se obter o desejado retorno social, prático e econômico do artefato satelital, define-se bem o escopo e a finalidade na área militar, comunicacional e analítica almejada (Bringhenti \& Ambrosio, 2020).

Conforme NASA (2007), o processo de elicitação de requisitos e de restrições para um sistema espacial é iterativo (altera-se através de tentativas sucessivas de refinamento), recursivo (em que há repetição de uma rotina), e deve ser definido pela necessidade dos stakeholders e objetivo da missão, de modo a especificar entradas, saídas do sistema espacial, estabelecendo suas relações técnicas.

Sendo assim, há três tipos de requisitos definidos por Wertz \& Larson (2011). No processo mencionado, um requisito deve ser definido na característica de atributo, função ou qualidade, para se especificar no sistema. Os requisitos funcionais são para definir a execução de funções, desempenho e tarefas a fim de um dado objetivo. Os requisitos operacionais são para determinar características operacionais, ergonômicas, de manutenção, de confiabilidade, relacional e outras, tendo em vista, o funcionamento do sistema espacial na missão. As restrições da missão são medidas de limitação, aplicadas com rigor, com ato ou efeito de restringir considerações funcionais, políticas, físicas, econômicas e estratégicas, observadas no desenvolvimento da missão.

Sobre as etapas de uma missão, Wertz e Larson (2011) afirma que a Pré-Etapa A estuda conceitos avançados para criar soluções tecnológicas segundo a noção inicial de necessidade e viabilidade, e de modo a verificar o cumprimento com o planejamento e a proposta inicial. Na etapa A, determina-se estudo de viabilidade, de risco, custos, demandas, cronograma e requisitos de um novo sistema espacial, fornecendo subsídio para projeto preliminar, na Etapa B. A Etapa C compreende o detalhamento do sistema de todos os subsistemas e o sistema de operações, para execução da fase D de fabricação, teste e integração. A Etapa E consiste em operar e manter o sistema funcional, recebendo informações do satélite para monitoramento e para atingir a missão, enquanto a Etapa F finaliza a missão, colocando o satélite numa órbita inativa.

${ }^{18}$ Imagem original acessada em 10 de outubro de 2021, disponível em: http://www.inpe.br/amazonia1/amazonia.php. 
No Quadro 1 a seguir demonstra o ciclo de vida de um projeto espacial, tendo base NASA (2007). Observou-se a formulação do projeto (estudos conceituais, desenvolvimento conceitual e projeto preliminar), juntamente, com a etapa C (Projeto Final e Fabricação) já enquadrado no desenvolvimento, que no Amazonia-1 ocorreram em conjunto entre 1980 à 2001, até iniciar a primeira fabricação da PMM. Em seguida, a etapa D (montagem, integração, teste e lançamento) ocorreu de 2001 2021, embora seu desenvolvimento seja definitivamente concluído em 2008. A etapa E (operação e manutenção) está em atual vigência. $\mathrm{O}$ projeto por sua característica iterativa e recursiva pode ser revisado quando necessário.

Quadro 1: Etapas de ciclo de vida de um projeto espacial da NASA.

\begin{tabular}{|c|c|c|c|c|c|c|}
\hline \multicolumn{3}{|c|}{ Formulação } & \multicolumn{4}{c|}{ Implementação } \\
\hline Pré-Etapa A & Etapa A & Etapa B & Etapa C & Etapa D & Etapa E & Etapa F \\
\hline Estudos de & Desenv. & Projeto & Projeto Design & Montagem, & Operação e & Fim da \\
Conceito & Conceitual & Design & Final e & Integração, & Manutenção \\
& Tecnológico & Preliminar & Fabricação & Teste, \\
& & & & Missãa & \\
\end{tabular}

Fonte: Adaptado de NASA (2007) pelos autores (2022) ${ }^{19}$.

Conforme Bringhenti e Ambrosio (2020), no avançar do projeto nas etapas de formulação e produção, cada tomada de decisão deve ocorrer para refinar e testar os requisitos e métodos na prática visando a otimização. Isto, porque, tecnologias espaciais raramente podem ser modificadas quando operantes no espaço. Assim, para que a tecnologia possa evoluir para uma especificação efetiva e com êxito, além de diminuir as chances de falhas operacionais, o artefato deve ser reformulado sucessivamente até se atingir o máximo custo-benefício, no sentido de eficácia e eficiência.

Factualmente, o desenvolvimento do Amazonia-1 como um sistema tecnológico espacial de alta complexidade, tem cumprido com o ciclo produtivo completo até a fase da Etapa E, sob atuação proeminente brasileira. Silva A. (2021) afirma que este Satélite foi concebido para ser uma tecnologia pioneira no território brasileiro no sentido de domínio da fabricação de satélites.

\subsection{Definição Técnica - Amazonia-1: PMM, Carga Útil e Câmera WFI}

"Um satélite, na visão de subsistemas, pode ser dividido em: estrutura, suprimento de energia, controle de órbita e atitude, propulsão, comunicação e serviço, gestão de bordo, controle térmico e carga útil” (Vinci \& Saotome, 2009, p. 1). Sugerido por Francisco (2003, p. 6), "no âmbito do segmento espacial encontram-se a carga útil (conjunto de equipamentos dedicados à aplicação da missão espacial) e a plataforma (conjunto de subsistemas projetados para sustentar a operação da missão em órbita, também referenciada por "bus")".

A Plataforma Multimissão (PMM) é um módulo no formato de cubo, que estrutura o satélite, equipa-o com funções básicas, tais como, controle térmico, comunicações, geração de energia elétrica, monitoramento, orientação e a carga útil do artefato (Silva et al. 2019²0; Inácio \& Pin, 2020). Segundo Silva et al. (2014), a PMM possui uma arquitetura modular compacta para suportar vários tipos de missão de baixa órbita terrestre no tocante a satélites da classe de $500 \mathrm{~kg}$ a $700 \mathrm{~kg}$, na Figura 4 .

\footnotetext{
${ }^{19}$ Revisão Preliminar de Projeto (PDR): Fase B e C; Revisão Crítica de Projeto (CDR): Fase C e D; Revisão de Prontidão de Voo (FRR): Fase D e E.

${ }^{20}$ Informação concedida no período a National Geographic entrevista a Adenilson Roberto da Silva, coordenador de Satélites Baseados na PMM do INPE e Cláudio Almeida, tecnologista sênior do Inpe e coordenador do programa de Monitoramento da Biomas, a incluir a Amazônia.
} 
Figura 4: Visão Aberta da Plataforma Multimissão (PMM).

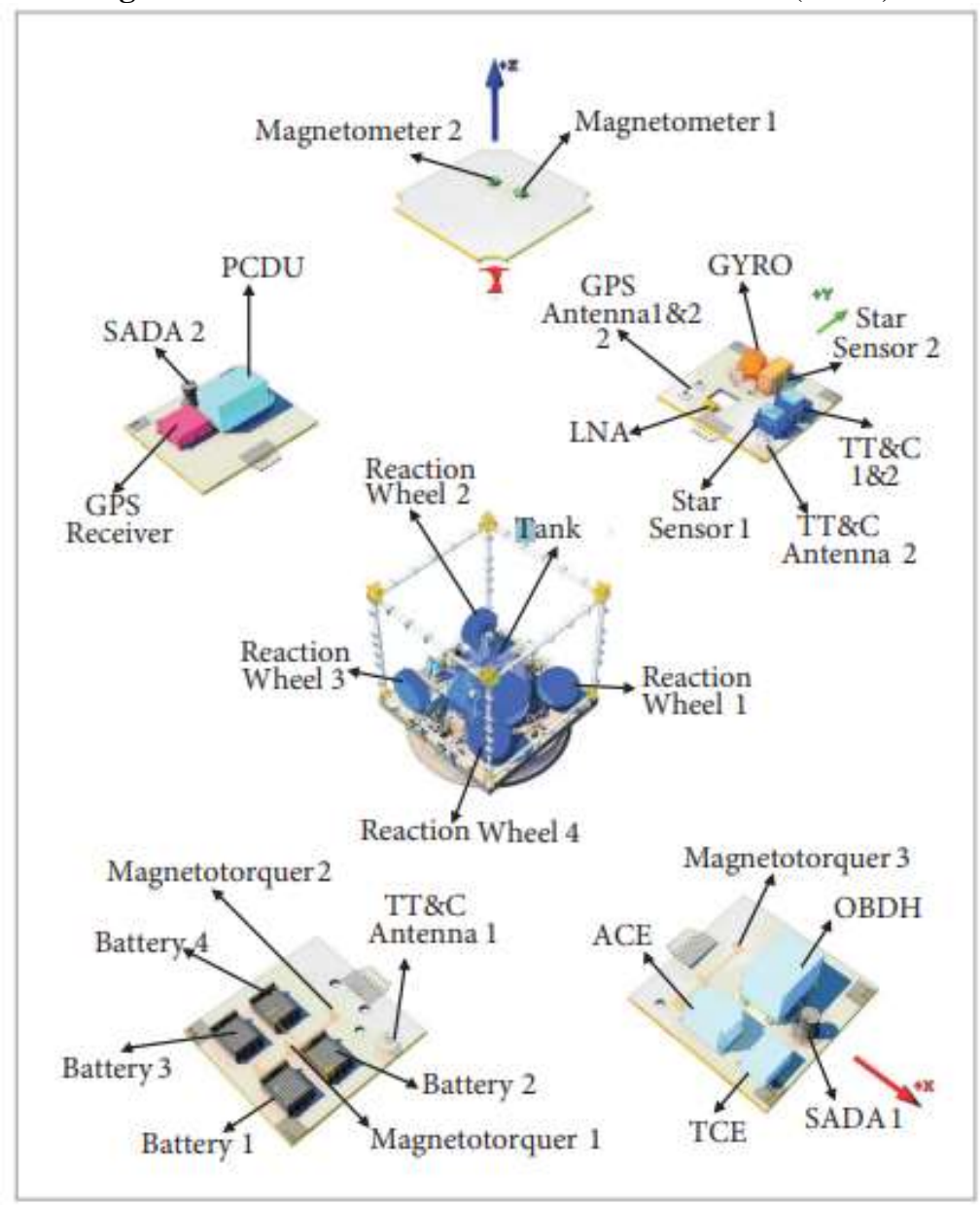

Fonte: Silva et al. $(2014)^{21}$.

A plataforma é destinada à observação de objetos no espaço em missões científicas e no planeta Terra. A PMM foi projetada para ser operada entre $600 \mathrm{~km}$ a $1.200 \mathrm{~km}$ de altura em diferentes órbitas ${ }^{22}$ terrestres do planeta. Segundo Moura et al. $\left(2021^{23}\right)$, a PMM possui painéis laterais, integradores das tecnologias de suprimento de energia, comunicação, propulsão (motor), controle de atitude e órbita para rotação de bordo e da própria estrutura do satélite e outras. Este módulo estrutura os painéis solares (formato semelhante ao planador), constituindo-se uma firme base estrutural do satélite para estrutura superior, no caso, o módulo de Carga Útil. A PMM suporta o peso entre $250 \mathrm{~kg}$ a $300 \mathrm{~kg}$ numa órbita baixa, até portando cargas úteis de satélite geoestacionário.

A Carga Útil contém a câmera imageadora e equipamentos de gravação e transmissão de dados. A Figura 5 ilustra no centro da imagem, o Subsistema Estrutura Mecânica na Carga Útil. Este subsistema tem por função acondicionar e blindar os equipamentos de Carga Útil no ambiente espacial, inóspito e agressivo, além de ser um porta-equipamentos e conter outras funcionalidades. É um módulo que abriga os equipamentos Subsistema WFI, RTU, Conversores DC/DC, Subsistema Gravador Digital de Dados (DDR) e Subsistema Transmissor de Dados da Câmera (AWDT) (INPE, 2021) ${ }^{24}$.

\footnotetext{
${ }^{21}$ Imagem acessada em 13 de janeiro de 2022, disponível em: http://www.inpe.br/amazonia1/sobresatelite/pmm.php\#5.

${ }^{22}$ As órbitas Polar, equatorial e de baixa inclinação, no caso desta última, a heliossíncrona.

${ }^{23}$ Informação concedida para o período na entrevista de Marcos Chamon, Coordenador de Planejamento e Monitoramento - INPE, ao canal MundoGEO.

${ }^{24}$ Disponível em: http://www.inpe.br/amazonia1/sobre_satelite/carga_util.php. Acesso em: 01/11/2021.
} 
Figura 5: Vista Aberta do Módulo de Carga Útil.

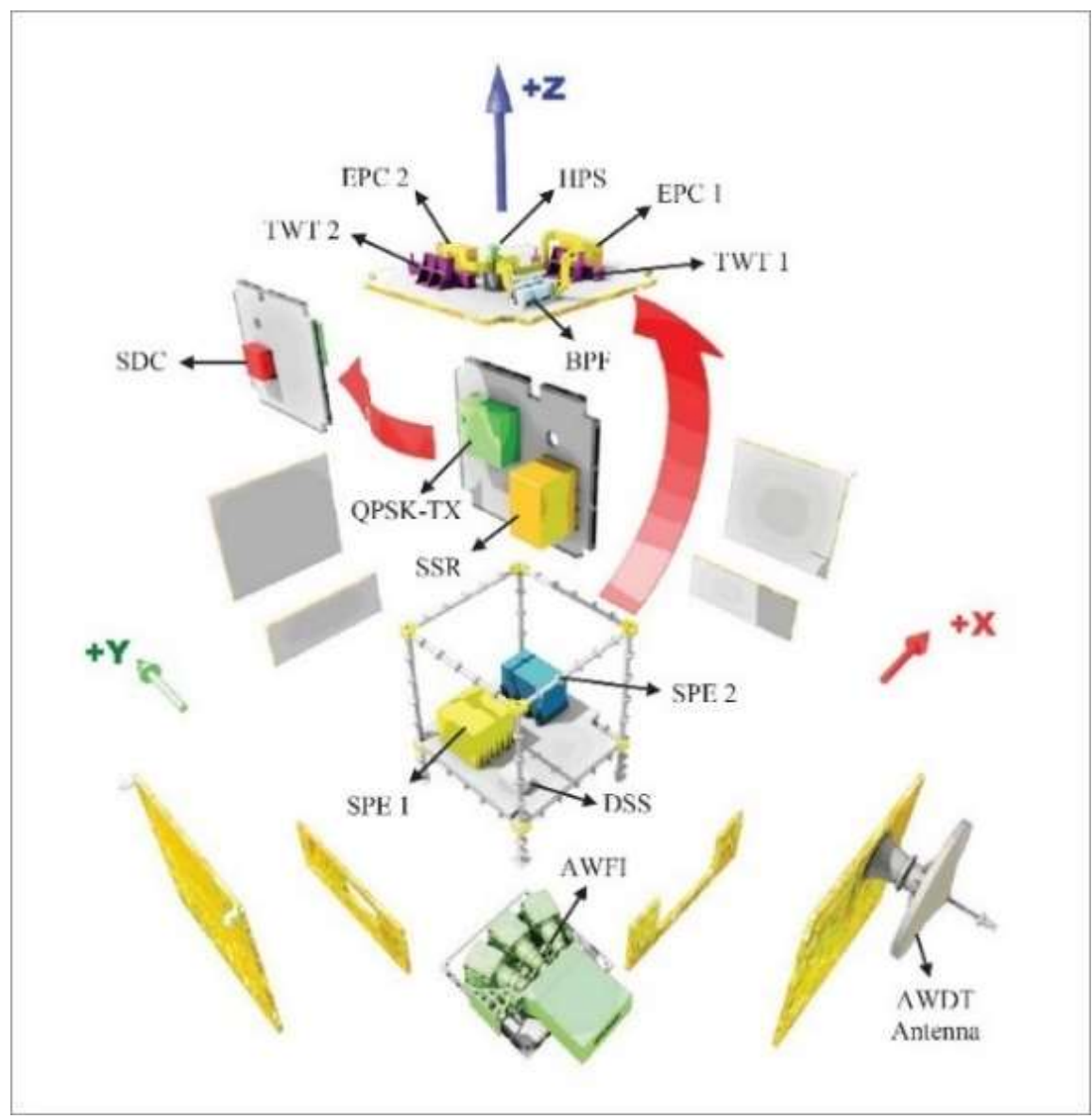

Fonte: Silva et al. $(2014)^{25}$.

A Figura 6 ilustra a estrutura do Satélite Amazonia-1; sendo os painéis de fechamento separados para demonstrar os equipamentos e subsistemas em sua organização interna, possuindo os dois módulos independentes já mencionados. O painel solar é configurado como na etapa de lançamento, colocando-se em uma posição retraída. O Módulo de Serviço, localiza-se abaixo na base estrutural, tratando-se da Plataforma Multimissão (PMM), enquanto que na parte superior, encontra-se o módulo de Carga Útil e de seus equipamentos de transmissão, gravação e para sensoriamento remoto.

Figura 6: Vista Aberta da arquitetura do Satélite Amazonia-1: PMM e Carga Útil.

(a) Satélite Amazonia-1

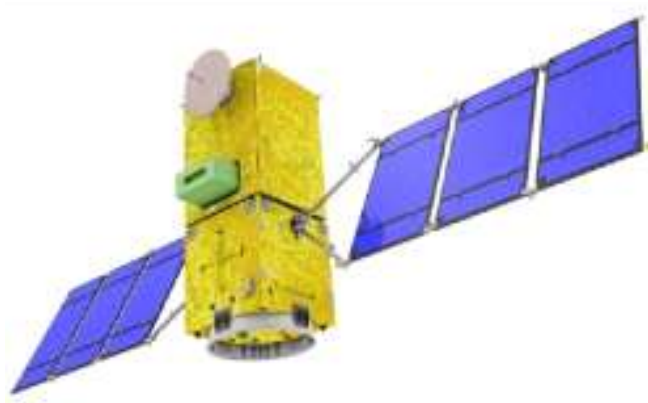

(b) PMM acoplada com Módulo de Carga Útil
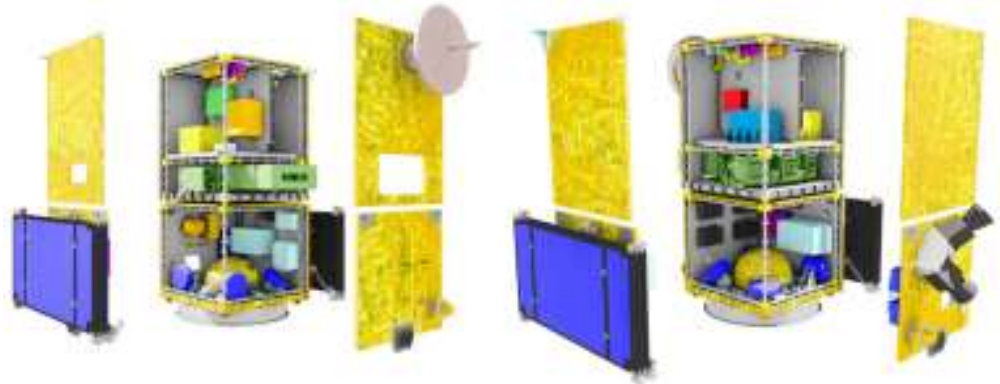

Fonte: INPE $(2021)^{26}$.

${ }^{25}$ Exploded view of the payload. Acesso em 11 de janeiro de 2022, disponível em: https://www.scielo.br/j/jatm/a/Q7yL3hT4Pd5Vk3MTJwcsbVR/?lang=en\#.

${ }^{26}$ Imagens acessadas em 2 de dezembro de 2021, disponível em: http://www.inpe.br/amazonia1/sobre_satelite/. 
Na Figura 7 adiante, a considerar a documentação ${ }^{27}$ da câmera fornecida pelo INPE (2018) no sistema de acesso à informação, a câmera WFI foi construída contendo um imageador, cuja captura de imagens e dados auxiliares do subsistema é processado na unidade de processamento (SPE), este último é ilustrado na Figura 8, posteriormente. O subsistema Gravador de Dados Digital (DDR) registra os dados e o Subsistema Transmissor de Dados da Câmera (AWDT) envia-os para as estações terrenas. A Unidade de Telemetria Remota (RTU) possui implementado uma interface de telemetria e controle remoto da câmera, que é alimentada pelo Conversor DC/DC.

Figura 7: Subsistemas do Módulo de Carga Útil - Câmera WFI.

(a) Câmera WFI

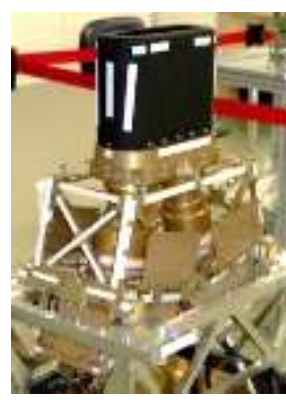

(b) Conversor DC/DC

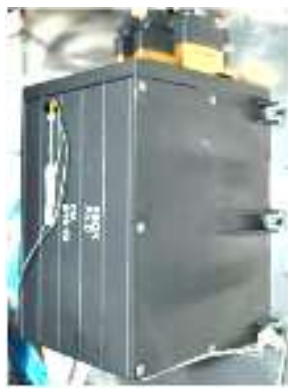

(c) Equipamentos e Antena AWDT

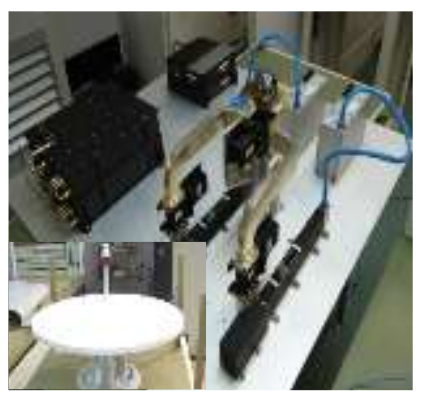

Fonte: INPE $(2021)^{28}$ (d) Gravador DDR

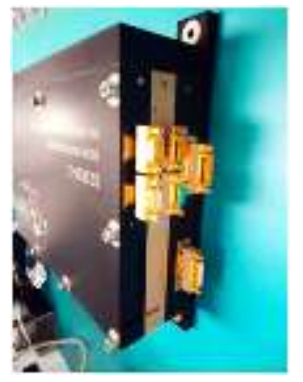

(e) Equipamento RTU

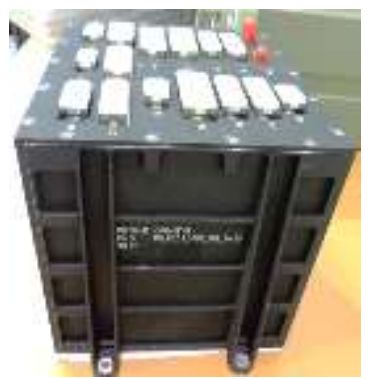

A seguir, Scaduto et al. (2019) explicam que há 3 (três) dispositivos que compõem o Subsistema de Câmera AWFI. Na Figura 8 (a) a seguir, o recurso Opto-Electronic Block (OEB), o Bloco Opto-Eletrônico possui unidades de detecção, calibração, assim como sensor eletrônico de proximidade, sob uma estrutura mecânica que contém 3 (três) canais ópticos idênticos; cada um destes canais, contendo um grupo de plano focal, um condensador e uma caixa de luz. No item (c) da Figura 8, o Signal Processing Electronics (SPE1) tem a capacidade de controlar o processamento, formatação dos sinais de vídeo e a autocalibração radiométrica, assim como o Thermal Control and Power Supply (SPE2) tem a função de transmissão de telemetria, temperatura, recepção de controle remoto, bem como fornecimento de energia.

Em paralelo, na parte (b) desta mesma Figura 8, demonstra-se o dispositivo de Canal Óptico (OC). Junior (2013) ${ }^{29}$ afirma que o sistema óptico, ao utilizar-se do OC contém as características técnicas de 34 barretes de 6034 detectores para detecção de referência, como também 6000 barretes de 6034 det. para formação da imagem. Para o item (d), observou que entre as imagens dos sistemas contíguos existem sobreposições no imageamento espacial. Na imagem, há regiões imageadas que se apresentam sobrepostas, uma sobre a outra, por onde a informação se repete e não conecta as imagens, e a correção dessa sobreposição, pode ser feita por algoritmo.

\footnotetext{
${ }^{27}$ A documentação da câmera foi obtida por e-mail utilizando o sistema de acesso à informação do INPE. In: INPE (2018, 11 de Maio). Documentação AMAZÔNIA1 SATELLITE - Amazônia 1 AWFI Subsystem Specification. A823600-SPC-001/02.

${ }^{28}$ Galeria de imagens acessada em 08 de dezembro de 2021, disponível em: http://www.inpe.br/amazonia1/galeria.php.

${ }^{29}$ Informação concedida no vídeo "Satélite Amazônia: a história não contada", do canal Brasil com Ciência para o período na entrevista de Heitor Patire Júnior, doutor em Engenharia Aeronáutica e Mecânica e Tecnologista no INPE.
} 
Figura 8: Componentes para funcionamento da Câmera WFI.

(a) OEB
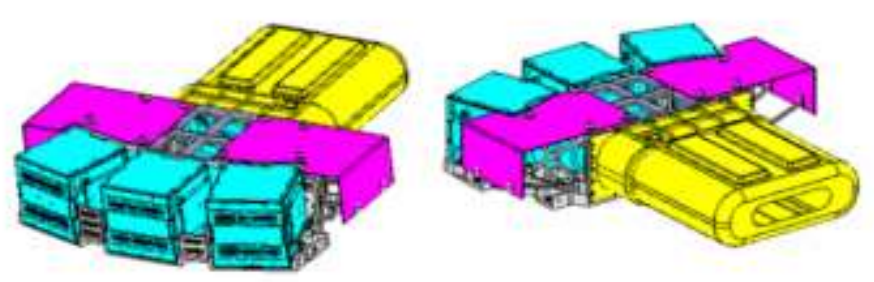

(c) SPE1 e SPE2

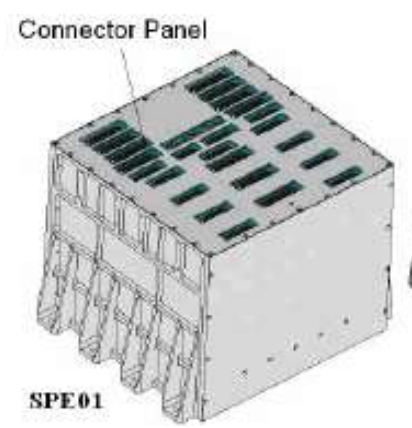

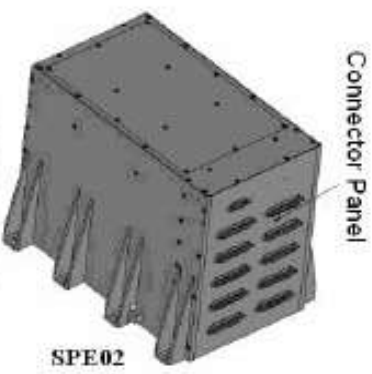

(b) Canal óptico (OC)
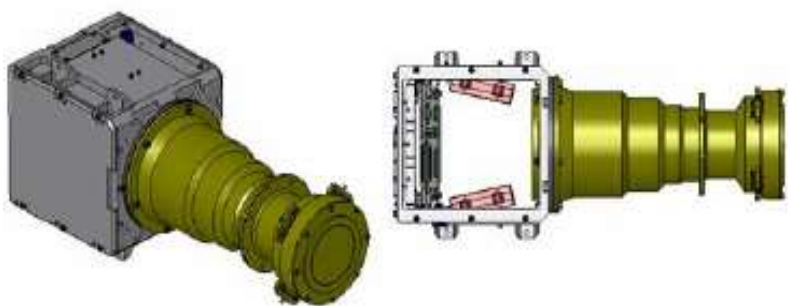

(d) Sistemas Ópticos e sua sobreposição

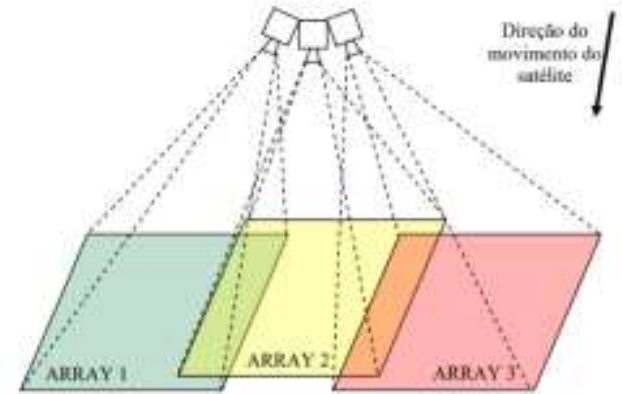

Fonte ${ }^{30}$ : Adaptado de (a, b, c) Scaduto et al. (2019) e (d) Junior (2013).

Segundo Moura et al. (2021) ${ }^{31}$, a câmera WFI evoluiu para frequência de resolução entre $\sim 62 \mathrm{~m}$ a $850 \mathrm{~km}$, e um pixel na imagem mede 60-65 metros, deste modo, está na categoria de baixa resolução espacial e sua finalidade é o monitoramento e mapeamento ambiental em larga escala, em semelhança aos sistemas espaciais de Landsat, CBERS, Dispositivos de Comunicação Satelital (SPOT, sigla em inglês) e outros. Conforme Castro Neto ${ }^{32}$ (2016), essa frequência obtida, é 3 (três) vezes maior do que a obtida pela série CBERS, exceto CBERS-4, diferenciando-se por alcançar 3 (três) bandas de frequência no espectro visível (VIS), além de captar Near Infrared (NIR, sigla em inglês) que atinge 1 (uma) banda próxima do infravermelho. Por exemplo, é possível visualizar grandes áreas de circulação de carros em Brasília no Distrito Federal ou também na cidade de São Paulo.

Conforme Nogueira e Barbosa (2021) ${ }^{33}$, o principal requisito e demanda foi obter imagens facilmente de áreas desmatadas e queimadas e não distinguir detalhes refinados comuns de atividades de espionagem, a exemplo de casas e carros. De tal modo, a relevância desta é justificada ${ }^{34}$ no uso para controlar o aumento dos índices recorrentes de áreas desmatadas e queimadas na Amazônia nas últimas décadas.

\subsection{Formulação do Amazonia-1: Do Contexto ao Projeto Preliminar (1980-2000)}

No Brasil na corrida espacial ${ }^{35}$, o presidente Jânio Quadros observando a necessidade do desenvolvimento de pesquisas

\footnotetext{
${ }^{30}$ Algumas imagens foram concedidas aos autores pela empresa Opto Eletrônica AS.

${ }^{31}$ Informação concedida para o período na entrevista de Marcos Chamon, Coordenador de Planejamento e Monitoramento - INPE, ao canal MundoGEO.

${ }^{32}$ Informação concedida no período à Agência USP na entrevista de Dr. Jarbas Caiado de Castro Neto, acionista do Grupo de Óptica (OPTO), do IFSC/USP, docente e empreendedor.

${ }^{33}$ Informação concedida no Canal Mensageiro Sideral na entrevista de Cássio Barbosa, Astrofísico e professor do Centro Universitário da Fundação Educacional Inaciana (FEI).

${ }^{34}$ Ao mesmo tempo, que não se descarta a importância de se atender a demanda por imagens com alta resolução espacial e temporal para melhor identificação dos alvos terrestres, pois obtém maior eficácia na visualização da variedade de fenômenos atmosféricos e terrestres no território brasileiro. Além de possibilitar a identificação e o mapeamento do mosaico diversificado da cobertura do solo e da vegetação, inclusive da agricultura; bem como das áreas dos lotes de desflorestamento (ou desmatamento), reduzidos de forma crescente (INPE, 2020). Disponível em: http://www3.inpe.br/crs/crectealc/pdf/tania.pdf. Acesso em: $12 / 11 / 2021$.

${ }^{35}$ A partir de 1957, os primeiros satélites artificiais, o Russo Sputnik e os norte-americanos do Projeto Vanguard, foram lançados no espaço. As potências mundiais, Estados Unidos da América (EUA) e União Soviética (URSS) abriram fronteira para a corrida espacial no mundo no período da guerra fria (EPIPHANIO, 2003).
} 
espaciais, como veículos lançadores e satélites, além do objetivo de explorar o espaço, o Programa Espacial Brasileiro (PEB) foi iniciado em 1956 (Epiphanio, 2003). A seguir, o Quadro 2 sintetiza o contexto de mudanças históricas, anterior à aprovação do MECB. De fato, houveram ações para estruturação do Setor Espacial Brasileiro, tais como, a criação de autarquias estatais e de seus objetivos, divisão das responsabilidades, lançamento de sondas, qualificação da equipe, cooperação internacional e outros.

Quadro 2: Marcos históricos do Programa Espacial Brasileiro (1960-1980).

\begin{tabular}{|c|c|c|}
\hline \multicolumn{3}{|r|}{ Contexto Histórico } \\
\hline Ano & Categoria & Descrição \\
\hline $1941-60$ & Criação das Autarquias & $\begin{array}{l}\text { O Decreto n }{ }^{\circ} 1.133 \text { instituiu o Grupo de Organização da Comissão Nacional de Atividades } \\
\text { Espaciais (GOCNAE), entre outros. Logo depois, foram criados o Ministério da Aeronáutica } \\
\text { (MA) em 1941, o Centro Técnico da Aeronáutica (CTA) em 1946, o Instituto Tecnológico } \\
\text { de Aeronáutica (ITA) em } 1950 \text { e o Instituto de Pesquisa e Desenvolvimento (IPD) em 1954; }\end{array}$ \\
\hline $1964-70$ & $\begin{array}{c}\text { Divisão de } \\
\text { Responsabilidades }\end{array}$ & $\begin{array}{l}\text { As atividades espaciais foram divididas nos setores civis e militares. Na área militar, a criação } \\
\text { do Grupo Executivo e de Trabalho e Estudos de Projetos Espaciais (GETEPE), com tempo } \\
\text { tornou-se Instituto de Atividades Espaciais (IAE). Na área civil, a evolução das atividades da } \\
\text { Comissão Nacional de Atividades Espaciais (CNAE), com tempo foi efetivada para se tornar } \\
\text { o INPE; }\end{array}$ \\
\hline 1965 & Lançamento e Qualificação & $\begin{array}{l}\text { A Missão Sondagem Aeronômica com Foguetes (SAFO) foi o primeiro lançamento com êxito } \\
\text { e tinha o objetivo de qualificação da equipe em áreas relacionadas às atividades espaciais do } \\
\text { projeto; }\end{array}$ \\
\hline $1956-68$ & $\begin{array}{l}\text { Cooperação } \\
\text { Externa e Qualificação }\end{array}$ & $\begin{array}{l}\text { Obteve-se a experiência educacional, na parceria com país Estados Unidos da América } \\
\text { (EUA) referente a montagem de uma estação de rastreio no arquipélago de Fernando de } \\
\text { Noronha, que foi o primeiro contato em } 1956 \text { com atividade espacial. Após isto, em 1968, } \\
\text { por meio do programa South Atlantic Anomaly Probe. Ambas as experiências ocorreram no } \\
\text { treinamento da equipe para lançamento e construção de foguetes; }\end{array}$ \\
\hline 1969 & Lançamento & O primeiro foguete, Sonda II foi ejetada no ambiente espacial; \\
\hline 1971 & Criação do IAE e INPE & $\begin{array}{l}\text { A extinção do Grupo Executivo e de Trabalho e Estudos de Projetos Espaciais (GETEPE) } \\
\text { para exercício do Instituto de Atividades Espaciais (IAE), assim como a substituição da } \\
\text { Comissão Nacional de Atividades Espaciais (CNAE) pelo Instituto Nacional de Pesquisas } \\
\text { Espaciais (INPE); }\end{array}$ \\
\hline $1970-80$ & $\begin{array}{c}\text { Cooperação } \\
\text { Externa e Qualificação }\end{array}$ & $\begin{array}{l}\text { A aproximação estratégica do Brasil com a China, e de alguns países africanos e da França } \\
\text { em acordos para treinamento de engenheiros no desenvolvimento de lançadores e satélites; }\end{array}$ \\
\hline 1976 & Lançamento & O primeiro voo do foguete Sonda III foi lançado; \\
\hline 1979 & Aprovação da MECB & $\begin{array}{l}\text { Foi aprovada a Missão Espacial Completa Brasileira (MECB), proposta do Comitê Brasileiro } \\
\text { de Atividades Espaciais (COBAE), cujo objetivo é voltado para estabelecimento de } \\
\text { competências educacionais e tecnológicas no país. Pretendeu-se produzir e aprender sobre } \\
\text { centros de lançamentos, veículos lançadores e satélites, realizando a geração, projeção, } \\
\text { construção e operação de um programa espacial completo. }\end{array}$ \\
\hline
\end{tabular}

Fonte: Elaborado pelos autores a partir de informações de Antunes (2016).

Em 1980, a primeira versão do Satélite Amazonia-1, o SSR-1, possuía a proposta de substituir a órbita Polar pela órbita Equatorial Baixa, com foco de visualização da região amazônica nas latitudes de $5^{\circ} \mathrm{N}$ e $15^{\circ} \mathrm{S}$, seguindo a proposta da MECB. Isto porque, os satélites CBERS, a partir dos anos 80 já cobririam o giro da órbita polar heliossíncrona ${ }^{36}$ (Rudorff et al., 2003).

O documento MECB continha diretrizes visionárias para instituições envolvidas seguirem metas, como as ações de: a) Desenvolvimento satelital do SSR-1 e SSR-2 para sensoriamento remoto, sob o comando do INPE; b) Desenvolvimento dos

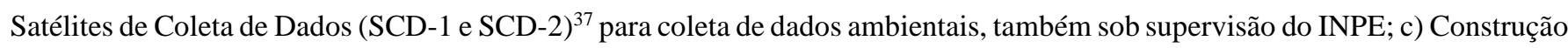
do campo de lançamento de foguetes e de satélites; d) Desenvolvimento de um Veículo Lançador de Satélites (VLS) para lançálos na órbita do planeta Terra (Orlando \& Kuga, 2007).

Neste contexto, o Satélite SSR-1 surgiu no território brasileiro alinhado aos objetivos dos planos ambientais em vigência na época. Em suas primeiras especificações, já havia a intenção de mudar o SSR-1 para órbita equatorial. A aplicação abrangeria

\footnotetext{
${ }^{36}$ Trata-se de um caso particular de uma quase órbita polar, pois seu plano de órbita é sempre fixo, ou seja, sempre passa aproximadamente sobre o mesmo ponto da superfície da Terra, todos os dias na mesma hora. Disponível em: <Órbita Hélio-Síncrona: Satélites (webnode.com)>. Acesso em: 26/09/2021.

${ }^{37}$ Atualmente, encontra-se atuante, mesmo com baterias debilitadas, afirma Heitor Patire Júnior, pesquisador do INPE, no vídeo "Satélite Amazônia: a história não contada", do canal Brasil com Ciência.
} 
a áreas específicas, como oceanografia, mineração, monitoramento de áreas agrícolas, identificação da radiação solar, desertificação em particular no Nordeste, desmatamento ilegal especialmente a Amazônia, caracterização e classificação da vegetação, geologia, queimadas e enchentes (Bogossian et al. 1995 \& Rudorff et al. 2003).

Nos esboços encontrados, o sensor remoto com a câmera WFI obteve uma tecnologia projetada inicialmente que equiparia futuramente satélites da série CBERS em 1999, assim como o projeto SSR-1, afirmam Rudorff et al. (2003). Esta câmera foi modelada inicialmente para suportar um imageador, com uma taxa de revisita a cada 5 dias, e para monitorar a cobertura da faixa equatorial extensa. Outro requisito importante da missão SSR era ter o peso de até $200 \mathrm{~kg}$, que é um nível de peso leve e viável na época para lançamento e equilíbrio no giro da órbita terrestre (Rudorff et al. 1996).

Neste período, a última revisão técnica no SSR-1 focou em aprimorar a câmera WFI e a parte estrutural do satélite. Como efeito, a resolução espacial teve que ser sacrificada a um parâmetro menor ( $260 \mathrm{~m})$, que é considerado um alcance médio na categoria de imagens de baixa resolução espacial (Epiphanio, 2003).

No tocante ao plano de mudança para órbita equatorial, não se obteve consenso entre os cientistas do INPE que concordaram pela órbita polar para manter a visualização de todo o território brasileiro e do globo terrestre, como também visando obter uma alta taxa de revisita das imagens, com atualização a cada 5 dias. Tal escolha, se feita, forneceria uma vantagem estratégica na obtenção de dados possíveis e significativos da superfície terrestre brasileira em maior quantidade. E por isto, a órbita Polar na direção Sol Síncrona foi adotada definitivamente para o Satélite SSR-1 (Rudorff et al. 1996).

A escolha da equipe científica pela órbita polar e da velocidade de sua frequência de giro na órbita a cada 5 (cinco) dias, forneceu como vantagem a possibilidade de monitoramento de todo território brasileiro, sob uma alta taxa de revisita; fator que superou problemas de imageamento que se tinha com as mudanças atmosféricas. Por exemplo, a visualização imediata do desmatamento ilegal possibilitaria acompanhar as invasões dos grileiros e madeireiros, ao avançarem além da fronteira agrícola na região amazônica; mesmo havendo, cobertura por chuvas ou nuvens em alguns dias na atmosfera. De fato, foi uma decisão estratégica acertada para combater o desmatamento, pois seria difícil escapar ileso, em 5 (cinco) dias (Castro Neto ${ }^{38}$, 2016).

Em 1990, houve outra maior revisão do projeto SSR-1, a preocupação seria de que se fossem desenvolvidos os dois satélites, o SSR-1 e o SSR-2, estes deveriam ser lançados em conjunto visando atender uma expectativa de vida útil de 4 anos. Em razão disso, a reformulação do projeto no momento focou em potencializar o veículo lançador de satélites para aumentar a expectativa de vida útil dos componentes tecnológicos (Bogossian et al. 1995 \& Rudorff et al. 1996).

A segunda versão projetada, o SSR-2, propunha a construção de um veículo lançador de satélites com peso de até 230 $\mathrm{kg}$, cuja estabilidade seria movida nos três eixos por motores alimentados pela hidrazina ${ }^{39}$. Tal tecnologia foi pensada para ajustar a posição, orientação e rota do artefato, em relação à Terra e de suas órbitas terrestres, fornecendo a possibilidade para focalizar melhor os pontos de visualização do planeta e também em casos de emergências pode apontar a câmera para qualquer ponto terrestre no prazo de dois dias (Rudorff et al. 1996).

Os SCDs (Satélite de Coleta de Dados) com peso de 115 quilos lançados em 1993 (SCD-1) e 1998 (SCD-2), possuíam uma engenharia que não permite posicioná-los na órbita, porque comportam-se como objetos que giram sempre envolta do próprio eixo, o que gera problemas se houver imprevistos ou mudanças no espaço. Na proposta do SSR-1, em caso de aproximarse da Terra por dezenas de metros, os propulsores do SSR-1 poderiam corrigir esses desvios de posição a cada ano, solucionando tal descoordenação (Breternitz ${ }^{40} \&$ Silva, 2021).

A versão, o SSR-2, se fosse desenvolvida seria necessário a criação de 2 ou até 3 sensores remotos com capacidade de

\footnotetext{
${ }^{38}$ Informação concedida no período a Agência USP na entrevista de Dr. Jarbas Caiado de Castro Neto, acionista do Grupo de Óptica (OPTO), do IFSC/USP, docente e empreendedor.

${ }^{39}$ Conforme Epiphanio (2003), é uma substância altamente tóxica, exige manuseio para proteção humana, sendo utilizada pela característica de oxidação, além de ser mais reativa que a amônia como combustível, ao mesmo tempo que torna o processo de abastecimento lento e arriscado.

${ }^{40}$ Informação concedida no período a Revista Pesquisa FAPESP na entrevista de Vivaldo José Breternitz, especialista no setor aeroespacial, da Universidade Presbiteriana Mackenzie, de São Paulo.
} 
captar a cobertura de $2.200 \mathrm{~km}$ da superfície terrestre brasileira com imagens sob uma resolução próxima tanto da linha do equador ( 100 m), como do limite de $15^{\circ} \mathrm{S}$ ( $200 \mathrm{~m}$ ) para atingir uma altitude da órbita de $893 \mathrm{~km}$, devendo permitir também imagear com uma resolução temporal no prazo de, aproximadamente, 2 horas (Rudorff et al. 1996).

Na década de 90, Brasil e China eram países emergentes dependentes de imagens e dados fornecidos pelos satélites dos países desenvolvidos da época. Para desenvolver na área, houve um acordo mútuo entre esses países visando a construção de satélites e foguetes. O primeiro país citado emprestaria seu domínio em alta tecnologia e seu parque industrial desenvolvido. O segundo daria sua experiência na construção de satélites e de foguetes lançadores (Costa Filho, 2006).

Em 1999, a partir desta parceria internacional, o subsistema Câmera WFI projetado na primeira versão para o então SRR-1, foi incorporado a bordo dos satélites da série CBERS ${ }^{41}$, que são artefatos gerados em colaboração com a China. Esta parceria proporcionou uma experiência positiva com a câmera WFI nos satélites CBERS, além de atestar a qualidade deste equipamento. Houveram avanços e melhoramentos no monitoramento no tocante a identificação do crescimento urbano, ocupação do solo, recursos hídricos, controle do desmatamento e queimadas na Amazônia legal, entre outras aplicações benéficas ${ }^{42}$, que poderiam ser posteriormente incorporadas no projeto do Satélite Amazonia-1 (Costa Filho, 2006).

Nos anos 2000, o projeto SSR-1 foi reformulado em seu planejamento, sendo revista a configuração dos módulos. No período, a AEB e o INPE decidiram desenvolver um componente para ser usado em diferentes missões, e que pudesse reunir uma única plataforma para todos os equipamentos de sustento da sobrevivência vital do artefato no espaço, que é a Plataforma Multimissão (PMM). No período, foi remodelado também o Módulo de Carga Útil, que contém sensores remotos para capturar imagens, assim como equipamentos de gravação e transmissão de dados, afirmam Silva et al. (2014).

A configuração dos módulos, de Carga Útil e PMM, foram concebidos para serem independentes um do outro. No período, o SSR-1 foi arquitetado para dispor de: i) Compressão de imagens embarcadas em satélite; ii) Dados da irradiação por imagem que seja transmitido diretamente para estações receptoras; iii) Três bandas visíveis na resolução de $~ 100 \mathrm{~m}$ a 200 m; iv) Banda infravermelho (infrared, IR) na resolução de $\sim 300 \mathrm{~m} \mathrm{a} 400 \mathrm{~m} \mathrm{e}$; v) Atender outros requisitos da missão, tais como, 4 anos de vida útil, obter peso no limite de $290 \mathrm{~kg}$ e adotar 250W de potência (Rudorff et al. 1996).

Também foi planejado como requisito funcional que a iluminação sobre a superfície terrestre brasileira forneceria as condições ideais de imageamento. Para isto, o satélite deveria ser colocado na direção Sol-síncrona, o que implica em adotar o tempo e a posição de passagem no imageamento do Norte em direção ao Sul do globo terrestre que passa exatamente na linha do equador às $10 \mathrm{~h} 30$ (Silva et al. $2019^{43}$ ).

No período anterior a 2001, Moura et al. (2021) ${ }^{44}$ afirma que a equipe envolvida trabalhou mais de 15 anos em testagem em protótipos, modelos maquetes e desenhos em duas versões do projeto SSR para então inaugurar a nova versão, o Satélite Amazonia-1, ao iniciar a fabricação das primeiras PMM.

\subsection{Missão Amazônia: Contexto, Experiências de Otimização e Fabricação (2001-2007)}

Ao final de 2001, a construção da Plataforma Multimissão (PMM) foi iniciada. Nos requisitos da missão, obteve-se objetivos de atingir o peso total entre $650 \mathrm{~kg}$ a $700 \mathrm{~kg}$, bem como a atualização e validação dos sensores da câmera ${ }^{45}$ WFI para

\footnotetext{
${ }^{41}$ Da série de satélites CBERS, foram lançados: CBERS-1 em 1999, CBERS-2 em 2003, CBERS-2B em 2007, CBERS-3 em 2013, CBERS-4 em 2014, CBERS$4 \mathrm{a}$ em 2019.

${ }^{42}$ Podemos citar aplicações, como: nas regiões agrícolas, zoneamento agrícola, gerenciamento de recursos hídricos, arrecadação fiscal, participação de outros programas ambientais e imagens para licenciamento.

${ }^{43}$ Informação concedida no período a National Geographic entrevista a Adenilson Roberto da Silva, coordenador de Satélites Baseados na PMM do INPE e de Cláudio Almeida, tecnologista sênior do Inpe e coordenador do programa de Monitoramento da Biomas, a incluir a Amazônia.

${ }^{44}$ Informação concedida para o período na entrevista de Marcos Chamon, Coordenador de Planejamento e Monitoramento - INPE, ao canal MundoGEO.

${ }^{45}$ Segundo o INPE (2021), referente a câmera AWFI, quanto ao quesito da resolução radiométrica em alvos específicos, deve-se obter a distinção e discriminação das diferenças sutis no brilho. Na resolução espectral, tanto na região espectral visível, referindo-se ao Infravermelho Próximo (NIR), quanto na região SWIR (infravermelho de ondas curtas). Ambos espectros se situam numa região espectral definida para sistemas ópticos (na área visível) projetados para análise de vegetação da cobertura terrestre. Para cada banda do NIR e SWIR, deve-se possuir 2 (duas) bandas (azul e vermelho) ou 3 (três) bandas (azul, verde e vermelho),
} 
obter melhoramento de sua espectroscopia para região visível (VIS) e para zona do infravermelho próximo (NIR) (Galvão ${ }^{46}$, 2021).

No período, era previsto que as espaçonaves americanas Acqua (EOS PM-1, na sigla em inglês) e Terra (EOS SER-2, na sigla em inglês), equipadas com os sensores Espectro Radiômetro de Resolução Moderada de Imagem (MODIS, na sigla em inglês) que obtinham resolução espacial de $\sim 250 \mathrm{~m}$ monitorando a região amazônica, seriam logo aposentadas. Então, para que o Software de Deteç̧ão do Desmatamento em Tempo Real (DETER) funcionasse em alta taxa de revisita a longo prazo, o Satélite Amazonia-1 teve que ser projetado para atuar em complemento com CBERS-3. E se possível, para atuar também com os satélites CBERS-4 e ao CBERS-4S quando fossem lançados para aumentar a frequência de imagens na região (Câmara ${ }^{47}$, 2012).

O Software DETER utiliza imagens com resolução espacial de $\sim 250 \mathrm{~m}$ a partir do MODIS. Sua interface emite alertas sobre alterações no desflorestamento (acima de 25 ha), atividade agrícola, zonas costeiras e desastres ambientais, especialmente para a Amazônia brasileira, tendo em vista, a diminuição dos índices de desflorestamento da Amazônia Legal. Se sincronizado, estes dois satélites mencionados poderiam obter uma alta taxa de revisita, para atualizar-se de 5 (cinco) a 8 (oito) dias. O artefato foi projetado também, para fornecer dados no intervalo de 2 (dois) dias de um ponto específico da Terra, a depender da demanda (Câmara ${ }^{48}$, 2012).

Na primeira construção da PMM, o artefato SSR evoluiu para o modelo do Satélite Amazonia-1. A partir de 2002, conforme Silva et al. (2021) ${ }^{49}$, os projetos de transferência de tecnologia espacial com base no PNDAE (2012-2021) destinaram cerca de $60 \%$ dos recursos orçamentários para capacitação técnica de empresas na área espacial. Com efeito, a PMM e demais dispositivos satelitais, tiveram o ganho e aprendizado pelo acompanhamento, supervisão e orientação do INPE.

Para construção satelital, segundo Silva et al. $(2021)^{50}$, um consórcio foi montado para concorrerem 5 empresas brasileiras especializadas em cada área produtiva. No evento, a empresa Fibraforte esteve responsável pelo Subsistema de propulsão. Na oportunidade, os pesquisadores do INPE forneceram conhecimento e experiência à empresa, já que tinham o aprendizado necessário desde a década de 90. Os primeiros propulsores de dois nêutrons do INPE evoluíram em alguns anos para um subsistema completo de propulsão operante na plataforma orbital. O INPE tinha intenção de produzir 6 (seis) propulsores, com 5 (cinco) nêutrons para o Amazônia -1 e testar na Câmara Anecóica.

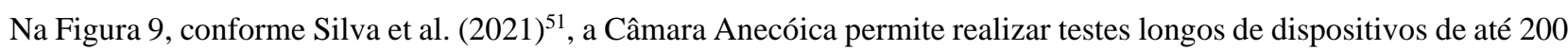
nêutrons na câmara de vácuo. Neste local, o ar é retirado e a temperatura controlada varia entre $-190^{\circ} \mathrm{C}$ e $150^{\circ} \mathrm{C}$. Acima desse limite, poderia ser utilizado a considerar casos específicos como a testagem de satélites geoestacionários. No entanto, o Brasil não possui um sistema de exaustão de gases, suficiente para suportar testes com propulsores acima de 200 nêutrons. Embora possa ser feito no teste do propulsor ao forçar o vácuo a partir das bombas, deve-se manter uma pressão negativa para simulação das condições inóspitas e agressivas do ambiente espacial; e nesse caso, o maior risco é a saturação de gases. Por exemplo, recentemente um motor de 220 nêutrons foi testado no banco de testes na cidade de Cachoeira Paulista (SP) por 5 (cinco) minutos e emitiu a mesma quantidade de gás de 20 carros dirigindo na via Dutra a mais de $100 \mathrm{~km}$ por hora. Tal volume significativo de gás gerado no teste indica que há um risco, impacto e consumo na atividade.

destinado a identificação de fenômenos específicos e relevantes na vegetação, a considerar o aspecto químico, estrutural e de umidade. Disponível em: <http://www3.inpe.br/crs/crectealc/pdf/tania.pdf>. Acesso em: 26/09/2021.

${ }^{46}$ Informação concedida no período a Brasil de Fato na entrevista de Ricardo Galvão, físico e ex-diretor do Instituto Nacional de Pesquisas Espaciais (INPE).

${ }^{47}$ Informação concedida no período a Revista InfoGEO na entrevista de Gilberto Câmara, cientista da computação e ex-diretor do INPE de 2005 a março de 2012.

${ }^{48}$ Idem: Informação concedida no período a Revista InfoGEO na entrevista de Gilberto Câmara.

${ }^{49}$ Informação concedida no vídeo "Satélite Amazônia: a história não contada", do canal Brasil com Ciência para o período na entrevista de Heitor Patire Júnior,

doutor em Engenharia Aeronáutica e Mecânica e Tecnologista do INPE.

${ }^{50}$ Idem: Informação concedida no canal Brasil com Ciência para o período na entrevista de Heitor Patire Júnior.

${ }^{51}$ Idem: Informação concedida no canal Brasil com Ciência para o período na entrevista de Heitor Patire Júnior. 
Figura 9: Câmara Anecóica Blindada.

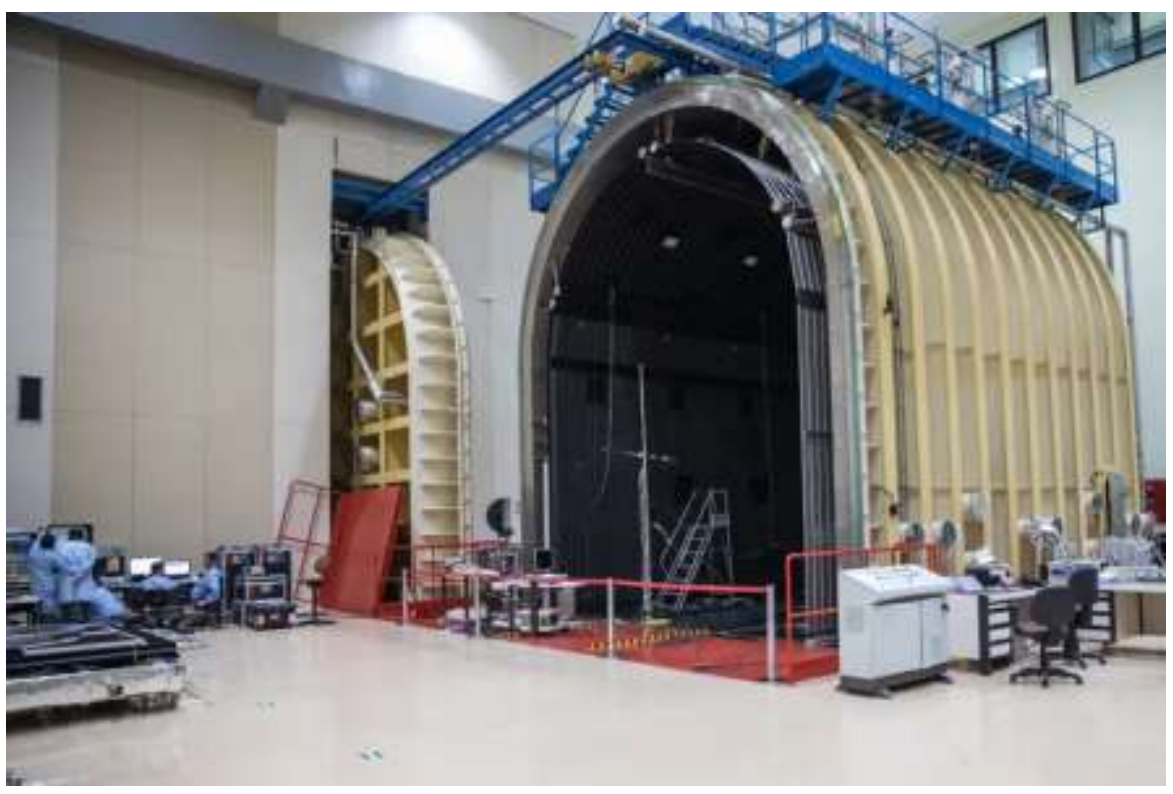

Fonte: Damásio $(2022)^{52}$

Na Figura 9 anterior, a Câmara Anecóica Blindada é o local no INPE onde o teste do termovácuo ocorre para simular as condições agressivas e rígidas do espaço. Na sala, é verificado a temperatura, radiação, pressão, diferentes níveis de vácuo, carga térmica que, em conjunto, incidem sobre a superfície do satélite. Além do mais, é testado as propriedades térmicas do sensor óptico colocando dissipadores elétricos de calor na superfície satelital (INPE $\left.{ }^{53}, 2021\right)$.

Em meados de 2001, foram feitas 2 (duas) plataformas PMM. Na primeira, houve um problema, onde uma das empresas parceiras do consórcio não cumpriu com o cronograma por problemas técnicos e financeiros na fase final de construção do dispositivo. E por isto, o Ministério Público Federal (MPF) brasileiro denunciou a empresa, de modo que ao abrir um processo jurídico, culminou-se no espólio judicial; e por esta razão, não pôde ser usada. Essa experiência demonstrou que a fabricação do dispositivo deveria ocorrer sem a formação de consórcio de empresas, a contratá-las de forma independente para contrato ter a possibilidade de ser facilmente cancelado ou substituído, afirmam Silva et al. (2021) ${ }^{54}$.

Em 2005, conforme o documento Programa Nacional de Atividades Espaciais - PNAE (2005-2014), o projeto Amazonia-1 passou a não ser prioridade no Setor Espacial Brasileiro. Em 2008, a AEB começou a dar prioridade novamente ao desenvolvimento da PMM, retomando a implementação do projeto Amazonia-1. Para isto, havia-se o entendimento de que seria necessário primeiro, uma nova definição de missão espacial. Paralelamente no INPE estavam sendo desenvolvidos vários módulos adicionais ${ }^{55}$ para testes, como a câmera WFI (Câmara ${ }^{56}$, 2012).

Em 2009, segundo Moura et al. $\left(2021^{57}\right)$ foi oficializado o desenvolvimento do Satélite Amazonia-1 com foco na testagem da Plataforma Multimissão em voo e da câmera WFI para o monitoramento do território brasileiro. O resultado positivo do teste da PMM forneceu a possibilidade de apresentar brevemente tal tecnologia no contexto internacional, para que pudesse

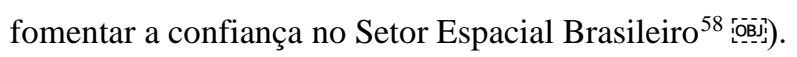

\footnotetext{
52 Acesso em 13 de janeiro de 2022, disponível em: https://kevindamasio.com/2019/11/01/natgeo-por-dentro-do-amazonia-1-primeiro-satelite-demonitoramento-100-brasileiro/.

${ }_{53}$ Acesso em 13 de janeiro de 2022, disponível em: https://www.lit.inpe.br/pt-br/ensaios_compatibilidade_eletromagnetica.

${ }^{54}$ Informação concedida no vídeo "Satélite Amazônia: a história não contada", do canal Brasil com Ciência para o período na entrevista de Heitor Patire Júnior, doutor em Engenharia Aeronáutica e Mecânica e Tecnologista do INPE.

${ }^{55}$ Conforme Moura et al. (2021), isto, porque, como regra operacional, são disponibilizadas 2 (duas) réplicas adicionais do SSR-1 para cada peça, seja de origem comprada no exterior ou produzida no Brasil; e que funcionou como um backup para substituição de componentes, se fosse necessário.

${ }^{56}$ Informação concedida no período a Revista InfoGEO por Gilberto Câmera, cientista da computação e ex-diretor do INPE de 2005 a março de 2012.

${ }^{57}$ Informação concedida para o período na entrevista de Marcos Chamon, Coordenador de Planejamento e Monitoramento - INPE, ao canal MundoGEO.

${ }^{58}$ Informação concedida para o período na entrevista de Carlos Moura, Presidente da AEB em 2021.
} 
Em 2010, Acaduto et al. (2010) afirma que a câmera AWFI foi desenvolvida pela empresa brasileira OPTO Eletrônica S.A para o Satélite Amazonia-1. Esta empresa também desenvolveu a câmera WFI por meio de um consórcio. Este último componente integraria os Satélites China-Brasil Earth Satélite de Recursos - CBERS 3 e 4.

A arquitetura e requisitos do Satélite Amazonia-1 na missão de 4 anos foi definida aproximadamente na versão apresentada por Silva et al. (2014). Esses autores afirmam que o satélite comporta a estrutura no formato de um paralelepípedo, com dimensões totais de 2.200 x 950 x 950mm, massa em cerca de 500,0 kg, estrutura em favo de mel de alumínio, $420 \mathrm{~W}$ de média potência, com painéis solares InGAP/InGaAs/Ge, bem como bateria de íon de lítio.

A considerar o cenário evolutivo, houveram sucessivas iterações no projeto para melhorar a definição do projeto, bem como executar a construção de soluções satelitais como as primeiras fabricações da PMM ou da câmera WFI. Sob adiamentos jurídicos ou políticos, o desenvolvimento da missão no período (2001-2007) avançou no sentido de refinar, fabricar e aperfeiçoar a especificação das restrições e requisitos, além de determinar o custo-benefício dos equipamentos.

\subsection{Satélite Amazonia-1: Contexto, Experiências de Implementação e Aprendizado (2008-2021)}

No fim de 2012, de acordo com Moura et al. $(2021)^{59}$ com vistas a simular as condições de vibração e acústica experimentada no decorrer do lançamento, foi construído uma cópia do satélite SSR-1 idêntica em modelo estrutural para ser submetido a testes mecânicos. Este protótipo era uma representação da dimensão estrutural e da massa do equipamento real.

Em 2013, o satélite CBERS-3 é o quarto satélite do programa a entrar em órbita. Neste ano, conforme o documento ${ }^{60}$, o Programa Nacional de Atividades Espaciais (PNAE) previa o atraso no desenvolvimento do projeto Amazonia-1 de, no mínimo, 2 (dois) anos na época. No documento, um dos objetivos demandados foi a testagem da vibração no modelo estrutural do Satélite Amazonia-1. Moura et al. (2021) ${ }^{61}$ afirma que o objetivo se materializou já no protótipo submetido a um conjunto de validações para verificar impactos vibratórios e acústicos, que poderiam ocorrer durante o lançamento.

De acordo com Genaro et al. $\left(2021^{62}\right)$, o teste eletromagnético do Amazonia-1 foi executado e busca garantir não haver interferência eletromagnética, e, interferências do satélite nos computadores da navegação dos veículos lançadores no momento de lançamento; demanda importante, pois, o artefato apresenta aproximadamente, 6 (seis) quilômetros de fio e 14.000 conexões elétricas, ilustra-se na Figura 10.

Segundo Moura et al. (2021) ${ }^{63}$ trata-se de uma sala que é uma escassa tecnologia no hemisfério sul e possui custo elevado. É uma ampla construção projetada em $10 \mathrm{~m}$ de altura com revestimentos de espumas em formatos pontiagudos para serem extremamente silenciosas do ponto de vista eletromagnético, isto é, sem eco; por onde não há perturbações eletromagnéticas, pois, as ondas sonoras de rádio não são refletidas. Na sala, avalia-se o comportamento do satélite sob efeito de ondas externas eletromagnéticas emitidas.

\footnotetext{
${ }^{59}$ Idem: Informação concedida para o período na entrevista de Marcos Chamon ao canal MundoGEO.

${ }^{60}$ Programa Nacional de Atividades Espaciais-PNAE: 2012-2021. Disponível em: https://www.gov.br/aeb/pt-br/programa-espacial-brasileiro/politicaorganizacoes-programa-e-projetos/copy2_of_PNAEPortugues_aeb.pdf. Acesso em: 01/11/2021.

${ }^{61}$ Idem: Informação concedida para o período na entrevista de Marcos Chamon ao canal MundoGEO.

${ }^{62}$ Informação concedida para o período na entrevista de Adenilson Roberto da Silva, doutor em Engenharia e Tecnologia Espaciais pelo INPE e gerente do Amazonia-1, no vídeo do canal Inpemct.

${ }^{63}$ Idem: Informação concedida para o período na entrevista de Marcos Chamon ao canal MundoGEO.
} 
Figura 10: Teste de Compatibilidade e Interferência Eletromagnética.

(a) Sala Projetada

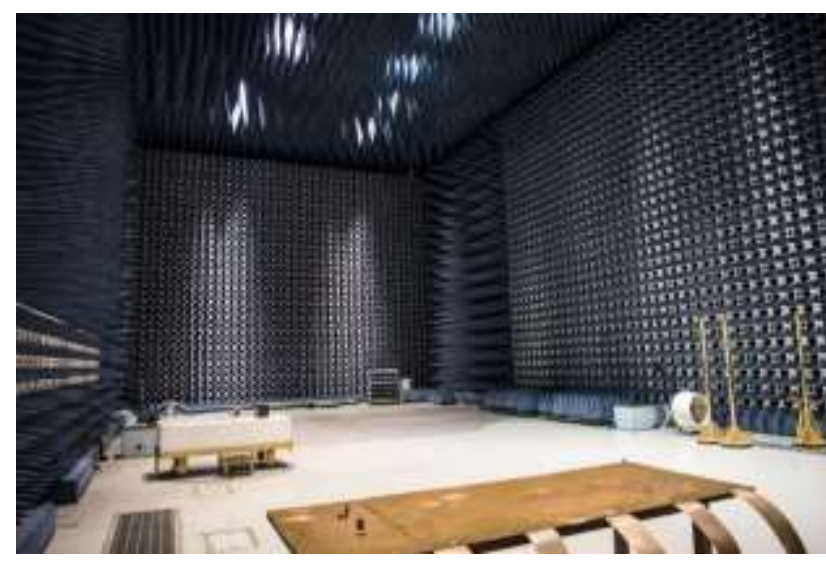

(b) Protótipo Instalado

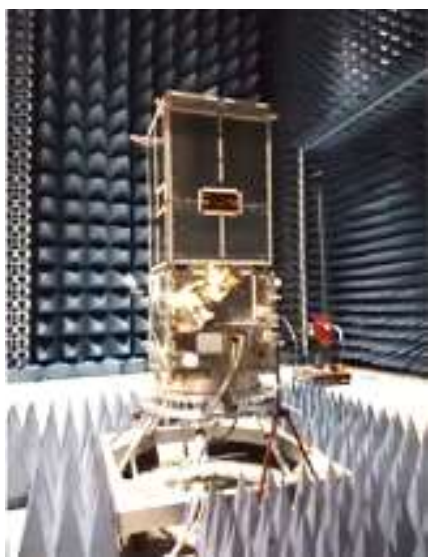

(c) Frente do Protótipo

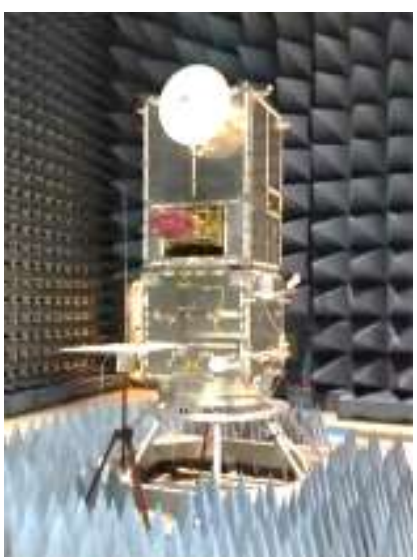

Fonte: (a) INPE (2021) ${ }^{64}$; (b e c) Inpemct $(2021)^{65}$.

Em 2014, segundo Silva et al. (2021) ${ }^{66}$, os propulsores foram validados e qualificados com êxito (Ex. Figura 11). O Subsistema de Propulsão contém a funcionalidade de elevação de órbita e de controle de altitude, e realiza movimentos bruscos para afastar-se da força gravitacional da Terra; enquanto que as rodas de reação realizam ajustes finos para apontamento da câmera WFI, da antena, etc. No eixo X ou Y são colocados 2 (dois) ativos e 2 (dois) reservas. Nos reservas, contém o catalisador brasileiro em fase de qualificação. A mudança dos propulsores nos dois eixos com 4 (quatro) propulsores alterna-se, e ao mesmo tempo, atua em conjunto, se acionados e, de acordo com a necessidade e intencionalidade do comando. Os propulsores são comandados para realizar manobras de elevação e ajuste nas órbitas terrestres com objetivo de alcançar a distância recomendada, quando naturalmente o satélite atrai-se pela gravidade do planeta Terra, sendo puxado em um movimento espiral descendente, até se atingir a distância de órbita mínima referente ao globo terrestre.

Figura 11: Teste no Modelo Subsistema Propulsão.

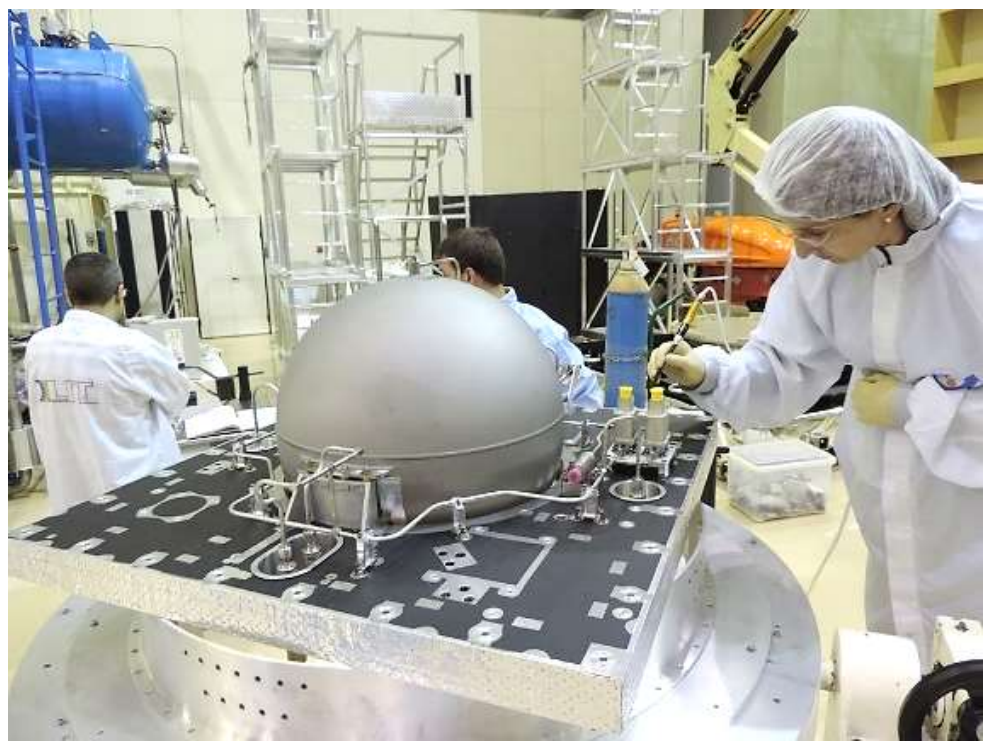

Fonte: INPE (2022) $)^{67}$

\footnotetext{
${ }^{64}$ Galeria de imagens INPE. Acesso em 11 de dezembro de 2021, disponível em: http://www.inpe.br/amazonia1/galeria.php.

${ }^{65}$ Captura de frame de vídeo em 19:39 minutos. Acesso em 15 de dezembro de 2021, disponível em: https://www.youtube.com/watch?v=aPPdfDKp81o.

${ }^{66}$ Informação concedida no vídeo "Satélite Amazônia: a história não contada", do canal Brasil com Ciência para o período na entrevista de Heitor Patire Júnior, doutor em Engenharia Aeronáutica e Mecânica e Tecnologista do INPE.

${ }^{67}$ Galeria de imagens, subsistema de propulsão. Acesso em 2 de janeiro de 2022, disponível em: http://www.inpe.br/amazonia1/galeria.php.
} 
Silva et al. (2021) ${ }^{68}$, notam que o fomento à educação espacial, incluso ToT, para desenvolvimento de propulsores, é um conhecimento em um nível crítico de relevância. Este subsistema mantém a sobrevivência da missão do satélite e dos veículos lançadores, e é vital para colocar cargas úteis no espaço, até para ir a outros planetas. Conhecimento aplicável também, para voo de mísseis nucleares e foguetes de grande porte, sendo uma vantagem bélica, científica e comercial, em um mercado restrito de países dominantes de tal conhecimento tecnológico. O Brasil nesse momento buscou desenvolver sua indústria siderúrgica pela relevância do conhecimento de propulsores na indústria espacial e devido a demanda para aumentar a capacidade de fabricação dos propulsores e de suas ligas metálicas. Há necessidade dessas ligas serem resistentes o suficiente para suportar intensas vibrações e choques de vários tipos de espectro durante o lançamento e na estadia espacial.

Silva et al. (2014) afirma que em 2014 que a criação da câmera AWFI com resolução espacial de $40 \mathrm{~m}$ teve possibilidade de incrementar uma melhora significativa na capacidade do subsistema da câmera a bordo. A câmera AWFI, se incorporada a bordo, aumentaria a performance do imageamento com imagens em 4 (quatro bandas), enquanto que na câmera WFI qualificada em voo no Programa CBERS atingiria somente duas bandas espectrais.

A partir de 2015, uma réplica térmica do satélite foi construída e arquitetada com massas térmicas e tubos da estrutura, para realização de testes de aquecimento ou congelamento. $\mathrm{O}$ artefato foi testado sob efeito de Matrizes de Radiação Infravermelha (IRA). As cargas térmicas das matrizes são postas na superfície do satélite têm a capacidade de simular as condições espaciais, a qual se é submetido no espaço, nos sensores, radiadores, atuadores de controle de temperatura, câmeras e antenas. Ao obter-se êxito no teste, foram incorporados melhoramentos térmicos no satélite, observa Moura et al. (2021) ${ }^{69}$.

Na Figura 12 a seguir, analisa Genaro et al. $\left(2021^{70}\right)$ o teste térmico dura em torno de 20 dias, e é feito uma simulação do ciclo de temperatura, oscilando entre quente (95 graus positivos) e frio (-95 graus negativos) no ambiente de vácuo. Objetivouse testar a resistência dos equipamentos em condições rígidas com vistas a garantir o controle térmico dos equipamentos, particularmente dos mais sensíveis, como computadores e eletrônicos. Essa simulação do ciclo de temperatura é necessária, porque o satélite é posto na órbita de $752,4 \mathrm{~km}$ sob a inclinação de $98,405^{\circ}$, realizando uma volta completa na Terra no prazo estimado de 100 minutos; sendo 65 minutos na parte iluminada, e 35 minutos na parte escura. Na parte iluminada, a superfície do satélite atinge 95 graus positivos, na parte escura atinge -95 graus negativos. Em 100 minutos, a variação da temperatura abrange uma escala de 200 graus sobre a superfície do satélite.

\footnotetext{
${ }^{68}$ Informação concedida no vídeo "Satélite Amazônia: a história não contada”, do canal Brasil com Ciência para o período na entrevista de Heitor Patire Júnior, doutor em Engenharia Aeronáutica e Mecânica e Tecnologista do INPE.

${ }^{69}$ Informação concedida na entrevista do Dr. Marcos Chamon (Coordenador de Planejamento e Monitoramento - INPE) no Canal MundoGeo.

${ }^{70}$ Informação concedida para o período na entrevista de Adenilson Roberto da Silva, doutor em Engenharia e Tecnologia Espaciais pelo INPE e gerente do Amazonia-1, no vídeo do canal inpemct.
} 


\section{Figura 12: Teste no Modelo Térmico.}

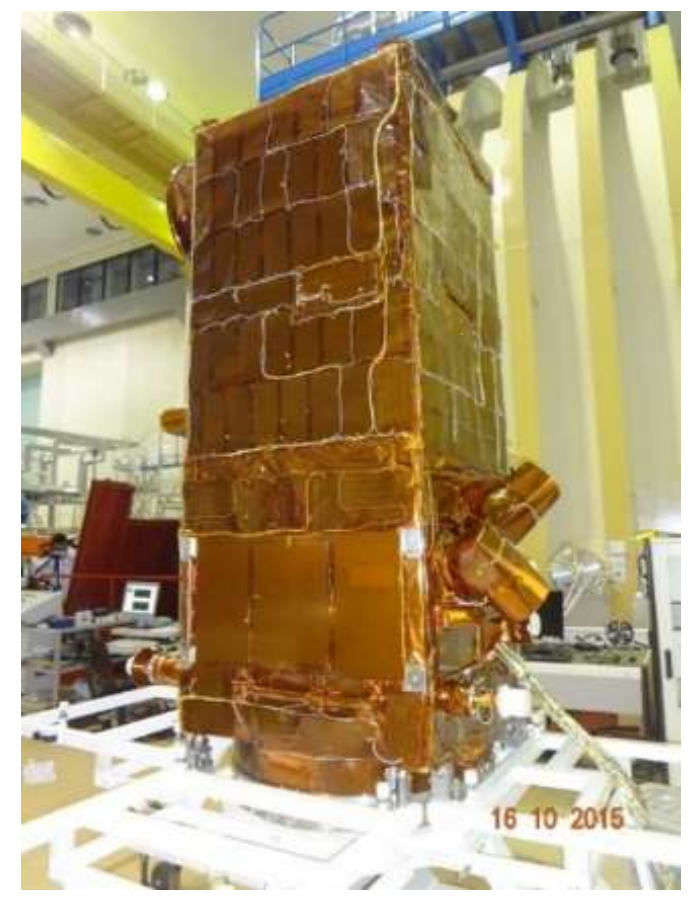

Fonte: INPE $(2021)^{71}$

Na Figura 12 acima, o satélite foi vedado por uma capa dourada intitulada Multilayer - MLI, que é um material para manter o controle de temperatura satelital. Esta manta protetora térmica possui uma composição de 15 a 20 camadas de materiais isolantes, cada qual com função térmica específica, e empacota o artefato funcionando como isolante, de modo a impedir que o calor entre na estrutura satelital, e se caso entrar, seja dissipado, afirmam Moura et al. (2021) ${ }^{72}$.

Na época, conforme Santos et al. (2021) ${ }^{73}$, um dos técnicos do INPE, Irlan Silva, foi estudar o Satélite Geoestacionário de Defesa e Comunicações (SGDC-1), em um intercâmbio na França. Ao observar a documentação do artefato, foi modelado um processo de engenharia para obter um aumento significativo no tempo de vida útil do dispositivo. Após realizado o protótipo, teste e validação, foi identificado uma maior eficácia na otimização da capacidade do tanque de combustível. Este importante ToT resultou em aprendizados, também foi programado para ser incorporado no modelo final do Amazonia-1.

Em 2016, foi realizada uma conjuntura de testes para integração do artefato, verificando interfaces entre os subsistemas e equipamentos, assim como no modelo elétrico e térmico para validar a compatibilidade elétrica, térmica e eletromagnética do satélite. No modelo térmico, não há equipamentos reais de voo, e foi testado um protótipo que representa a estrutura térmica do satélite. No modelo elétrico, são realizados testes nos componentes que possam suportar a radiação espacial. Há dispositivos, que mesmo funcionais e eficazes, seriam queimados no ambiente espacial, o que exige artefatos resistentes à radiação sob uma estrutura de proteção, bem como uma validação rigorosa para verificar os modelos de equipamentos que suportam tais condições rígidas e agressivas, não suscetíveis à radiação. No quesito eletromagnético, também se testa possíveis interferências espaciais para eliminá-las $\left(\right.$ Galvão $\left.^{74}, 2021\right)$.

\footnotetext{
${ }^{71}$ Galeria de imagens, Atividade Sistema - Modelo TBT/TVT. Acesso em 12 de novembro de 2021, disponível em: http://www.inpe.br/amazonia1/galeria.php.

${ }^{72}$ Informação concedida no período na entrevista de Marcos Chamon, Coordenador de Planejamento e Monitoramento - INPE, ao canal MundoGEO.

${ }^{73}$ Informação concedida para o período na entrevista de Carlos Eduardo Quintanilha, coordenador do segmento de solo da Diretoria de gestão e portfólio da Agência Espacial Brasileira, em entrevista ao Canal Bariogênese em 2021.

${ }^{74}$ Informação concedida no período a Brasil de Fato na entrevista de Ricardo Galvão, físico e ex-diretor do Instituto Nacional de Pesquisas Espaciais (INPE).
} 
O satélite tem, aproximadamente, 14.000 conexões elétricas, conforme Genaro et al. $\left(2021^{75}\right)$, e por isto, não é remota a possibilidade de ter fios invertidos ou conexões inadequadas na montagem. Se ocorresse esses problemas no momento que se separasse do lançador, o satélite apresentaria problemas de operação e não apontaria para a estrela solar. Pondo em risco à missão, uma vez que o artefato satelital não teria condições de obter energia solar, já que as placas solares não seriam abastecidas. Desta forma, os testes elétricos para verificação dos sistemas foram vitais para cumprimento da missão.

No modelo de voo do Amazonia-1 na Figura 13 (a, b, c) a seguir, segundo Silva A. R. (2021) ${ }^{76}$ por imaginar que no ambiente espacial não se realizaria reparos no artefato; a equipe foi incentivada a pensar em cenários hipotéticos de voo e programação, a supor quais comandos seriam necessários para consertá-lo em órbita, em caso de imprevistos e falhas no espaço. $\mathrm{Na}$ época, com mais de um ano de teste de voo no prazo de, aproximadamente, 2.000 horas de satélite ligado, garantiu-se que as funcionalidades implementadas estariam operantes de acordo com o planejado e seriam funcionais. Por exemplo, no modo de sobrevivência, o computador de bordo foi programado para ativar automaticamente se houvesse parâmetro anômalo. Este comando colocaria o satélite para girar e receber luz solar nos painéis solares; funcionalidade que certificaria o carregamento da bateria.

Nesse caso, Silva et al. (2014) afirma que na operação nominal a face do artefato estará apontada para a Terra; enquanto que em emergência o controle de atitude do satélite marcará para o Sol para abastecer o subsistema de propulsão, executando duas rotações por órbita para abastecer as baterias de forma balanceada.

Figura 13: Teste no Modelo de Voo.

(a) Frontal

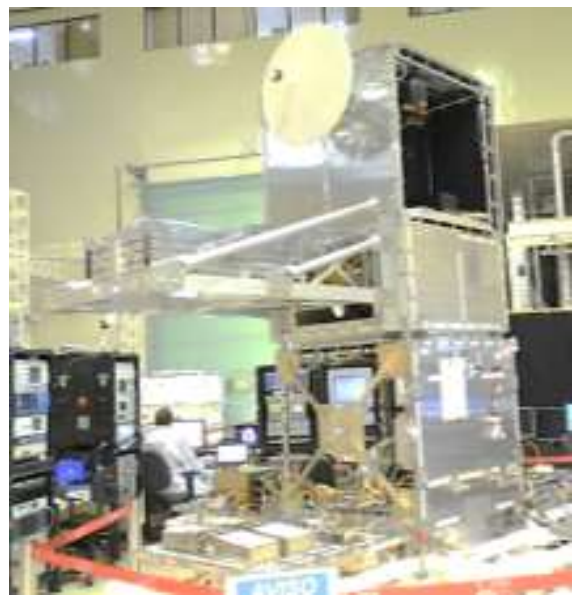

(b) Lateral

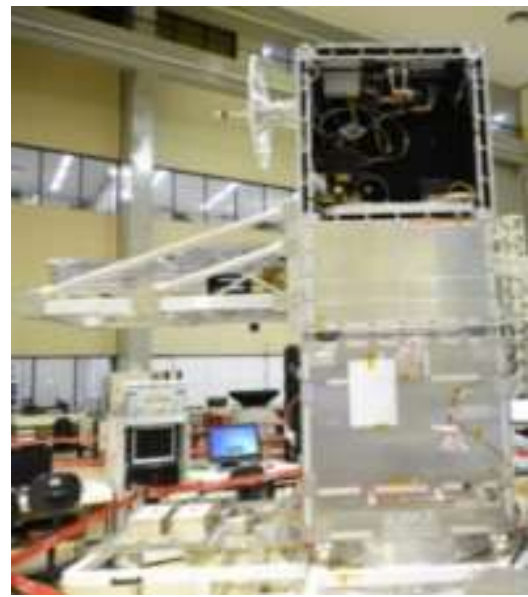

Fonte: INPE (2021) 77 (c) Traseira

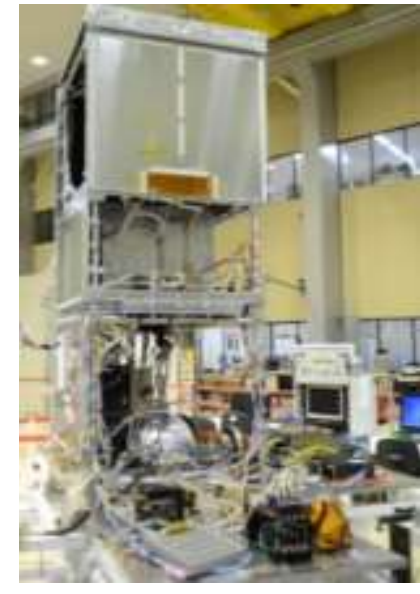

No período, um equipamento (formato de túbulo) foi exportado para Alemanha com vistas a realizar-se um tratamento térmico. Na ocasião, permaneceu retido devido a ameaças de sanção dos EUA, direcionada à empresa contratada e ao governo alemão, e foi liberado após negociações diplomáticas. De fato, na construção do satélite alguns países foram ameaçados de sanções comerciais e políticas se vendessem equipamentos espaciais para o Brasil. Isto motivou a importação de tecnologias espaciais advindas de países alternativos de maior economia e autonomia tecnológica, geralmente a China, Rússia e países da Europa. Essa escolha foi justificada para evitar o que vinha ocorrendo, em que o Departamento de Estado Americano (DoS) intervinha rigidamente e não autorizava a importação de peças para o Brasil, especialmente de finalidade militar, um exemplo

\footnotetext{
${ }^{75}$ Informação concedida para o período na entrevista de Adenilson Roberto da Silva, doutor em Engenharia e Tecnologia Espaciais pelo INPE e gerente do Amazonia-1, no vídeo do canal Inpemct.

${ }^{76}$ Idem: Informação concedida para o período na entrevista de Adenilson Roberto da Silva no vídeo do canal Inpemct.

${ }^{77}$ Galeria de imagens INPE. Acesso em 12 de janeiro de 2021, disponível em: http://www.inpe.br/amazonia1/galeria.php.
} 
foram as peças da PMM embargadas, afirmam Silva et al. $(2021)^{78}$.

Segundo Johnson-Freese (2007), a ação dos EUA é estratégica para evitar que qualquer país se coloque como potência militar e econômica, tornando-se um novo player no mercado internacional. Por consequência, para os países que produzem e detém tecnologias de uso duplo, dual-use technology, acabam tornando-se concorrentes para os EUA. Há uma lista de Tecnologias Militares Críticas do Pentágono, a Militarily Critical Technologies List (MCTL), em que cerca de 95\% das tecnologias espaciais são de uso duplo. Em 2018, a integração dos módulos foi iniciada; exemplo na Figura 14.

Figura 14: Integração dos Módulos.

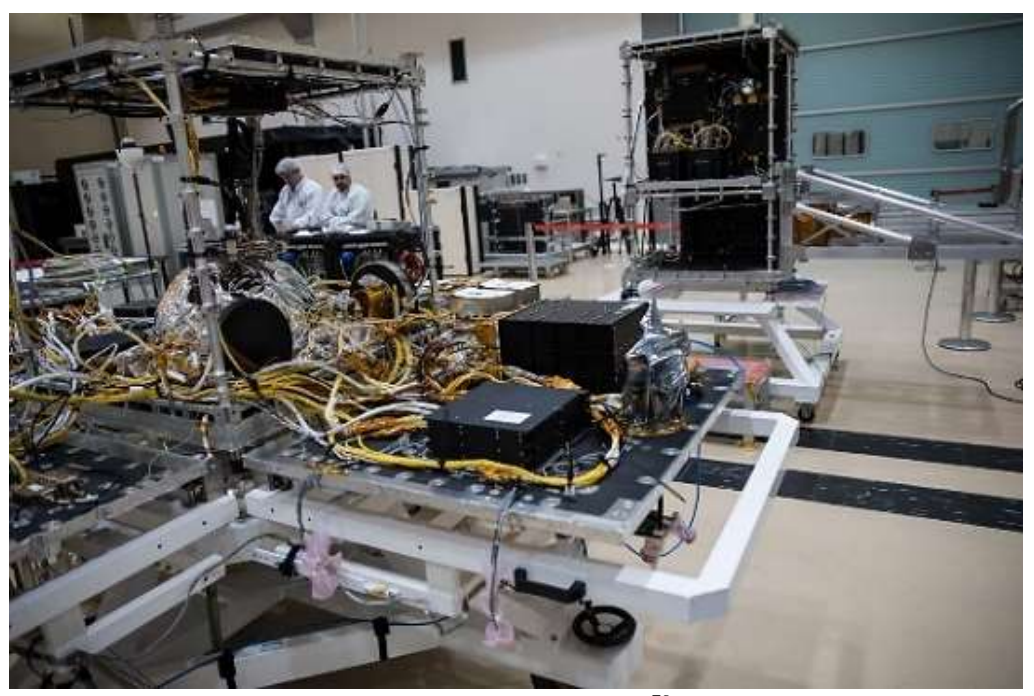

Fonte: Damasio (2022) ${ }^{79}$.

Conforme Moura et al. (2021) ${ }^{80}$ a Figura 14 ilustra a integração ocorrendo numa sala onde houve o comissionamento de partículas. Neste ambiente, os equipamentos foram provisionados e montados em condições de uma sala higienizada, além de ser controlado o nível de temperatura e poluição do ambiente.

No início de 2019, conforme Venticinque (2021) ${ }^{81}$ uma réplica estrutural do Amazonia-1 foi testada no modelo de engenharia. No ensaio, se examinou o funcionamento da separação do dispositivo acoplado ao foguete, e que no momento adequado será desmembrado durante o lançamento. Paralelamente, a integração dos painéis foi preparada, junto às verificações do setor elétrico, otimizando os pontos de conexão elétrica (aterramento) dos painéis.

$\mathrm{Na}$ área elétrica, para realização dos pontos de aterramento dos painéis solares é passado uma pasta de entrada, que aumenta o contato elétrico com os terminais, uma vez que quando os pontos estão isolados as cargas elétricas naturalmente são geradas. Para evitar este problema, as partes restantes devem ser conectadas eletricamente, sendo aterradas em seus pontos; já que o painel de forma ilustrada é uma folha de carbono acima de uma estrutura de alumínio, afirma Venticinque (2021) ${ }^{82}$.

A Figura 15 ilustra na primeira foto, o sensor solar montado nos painéis solares e, na segunda e terceira, o mecanismo

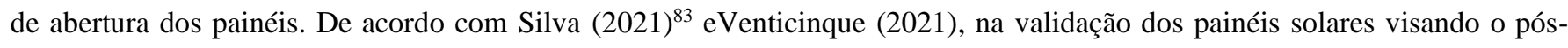
lançamento, os sensores solares foram iluminados, verificando o comportamento dos computadores de bordo na detecção de

\footnotetext{
${ }^{78}$ Informação concedida no vídeo "Satélite Amazônia: a história não contada”, do canal Brasil com Ciência para o período na entrevista de Heitor Patire Júnior, doutor em Engenharia Aeronáutica e Mecânica e Tecnologista do INPE.

${ }^{79}$ Acesso em 13 de janeiro de 2022, disponível em:https://kevindamasio.com/2019/11/01/natgeo-por-dentro-do-amazonia-1-primeiro-satelite-de-monitoramento100-brasileiro/.

${ }^{80}$ Informação concedida no período na entrevista de Marcos Chamon, Coordenador de Planejamento e Monitoramento - INPE, ao canal MundoGEO.

${ }^{81}$ Informação concedida na entrevista do Guilherme Venticinque (Gerente de Montagem, Integração e Testes - INPE) no Canal Inpemct.

${ }^{82}$ Idem: Informação concedida na entrevista de Guilherme Venticinque no Canal Inpemct.

${ }^{83}$ Informação concedida para o período na entrevista de Adenilson Roberto da Silva no vídeo do canal Inpemct sobre simulação de 100 horas em órbita e fechamento dos painéis laterais.
} 
energia solar e na execução do giro do satélite para captar iluminação. No teste, foi verificado o funcionamento das molas comprimidas no mecanismo de abertura dos painéis. Isto porque, os parafusos de selagem do painel solar são travas pirotécnicas para serem acionadas pelo computador de bordo, e quando queimadas, rompem-se para abrir seus mecanismos. Esses painéis solares devem funcionar de forma ininterrupta, a absorver energia durante a parte iluminada do artefato, e, durante a parte escura, para alimentar as baterias do satélite por 35 minutos.

Figura 15: Teste do Sensor Solar e do Mecanismo de Abertura do Painel Solar.

(a) Montagem do Sensor Solar

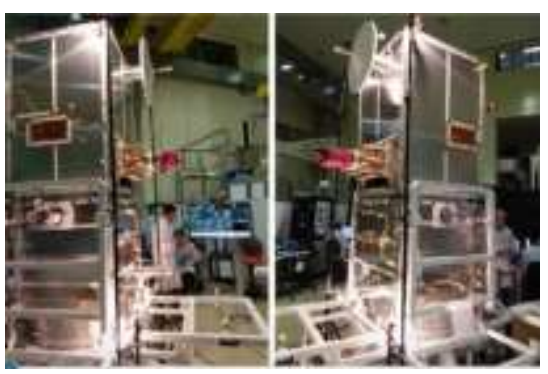

(b) Mec. de Abertura do Painel - Fechado

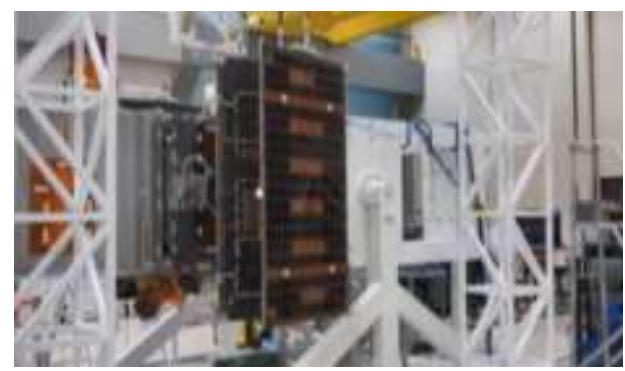

Fonte: Inpemct $(2021)^{84}$. (c) Mec. de Abe. do Painel - Aberto

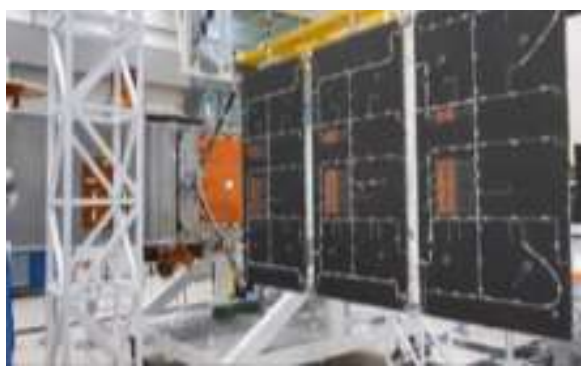

Em seguida, Moura et al. (2021) ${ }^{85}$ analisa que após dois painéis solares serem validados e integrados ao satélite foram realizados novamente testes dinâmicos de vibração e acústico. O satélite foi transferido e já montado em sua réplica elétrica com as medidas de comprimento para dentro de uma das 2 (duas) câmaras Anecóicas do INPE. Ao verificar o documento intitulado Typical day - AIT activities $^{86}$, que aborda as revisões da integração e testes, foi demonstrado que a atividade de colocação do satélite já instrumentado para teste dentro desta câmara termo vácuo, bem como o processo de despressurização para teste em vácuo, eram atividades dispendiosas cuja execução foi descrita na duração média de 12 horas.

Em 2020, as atividades de teste e validação do modelo elétrico e modelo de voo do Amazonia-1 foram realizadas. Em paralelo, também foram implementados os recursos de testes necessários à campanha de teste ambiental do modelo de voo (INPE, 2021) $)^{87}$.

Sobre as câmeras, embora em 2019, segundo Scaduto et al. (2019, p. 1) a Câmera AWFI iria integrar a carga útil do Satélite Amazonia-1. Em 2021, segundo INPE (2021) ${ }^{88}$ o imageador lançado no Amazonia-1 foi o modelo da Câmera WFI, cuja herança em voo foi obtida no Programa CBERS. Pelo fato descrito, a Câmera AWFI acabou não sendo incorporada nos subsistemas do Amazônia-1.

Na época, embora a aprovação da Lei do Marco Legal da Ciência e Tecnologia (MLCT) pela Lei 13.243 promulgada em 2016 tenha facilitado o firmamento de contratos entre empresas privadas e instituições de pesquisa governamentais. Ainda houveram dificuldades de adaptação e execução por parte dos órgãos de controle no processamento ágil dos contratos; a exemplo do caso da Consultoria Jurídica da União que devido a seu processo burocrático penoso na tramitação dos contratos, impediu que o INPE contratasse empresas brasileiras, o que prejudicou o fomento da indústria espacial. Somado a isto, havia-se o contexto de corte estatal onde o corpo técnico do INPE decresceu em cerca de 1.500 funcionários em 2010 para aproximadamente em 2020, 700 servidores; o que associado à vontade governamental de prorrogar para o plano quinquenal seguinte, teve-se o real risco de adiar o término do desenvolvimento do Satélite Amazonia-1 para quase uma década adiante, analisa Galvão ${ }^{89}$ (2021).

\footnotetext{
${ }^{84}$ Capturas de frame de vídeo. Acesso em 14 de dezembro de 2021. Disponível em: https://www.youtube.com/watch?v=aPPdfDKp81o.

${ }^{85}$ Informação concedida na entrevista de Marcos Chamon, Coordenador de Planejamento e Monitoramento - INPE, para o período ao canal MundoGEO.

${ }^{86}$ In: INPE. (2020) Typical day - Ait activities. Documento técnico de revisão de integração e teste.

${ }^{87}$ Disponível em: http://www.inpe.br/amazonia1/sobre_satelite/estagio_atual.php. Acesso em: 03/11/2021.

${ }^{88}$ Disponível em: http://www.inpe.br/amazonia1/sobre_satelite/carga_util.php. Acesso em: 01/11/2021.

${ }^{89}$ Informação concedida no período a Brasil de Fato na entrevista de Ricardo Galvão, físico e ex-diretor do Instituto Nacional de Pesquisas Espaciais (INPE).
} 


\subsection{Do Lançamento ao Sensoriamento - Satélite Amazonia-1: Planejamento e Operação}

O lançamento do Satélite Amazonia-1 conforme Nogueira \& Barbosa (2021 ${ }^{90}$, ocorreu em um período em que não se admitia o aumento do desmatamento o que ressaltou a importância da Missão Amazônia, havia-se a preocupação da comunidade científica com a manutenção e a evolução do patrimônio de desenvolvimento tecnológico do Setor Espacial Brasileiro.

A Lei 8.666, de 21 de junho de 1993 padronizou as licitações para todas as formas de contratação do governo, embora houvesse críticas quanto ao escopo jurídico limitado desta normativa, que possuía dificuldade em atender os requisitos e as demandas quando se trata de um produto de desenvolvimento tecnológico. O espectro de compras do governo é bastante amplo, obviamente necessitava-se de adaptações jurídicas para cada caso; e para o satélite não foi diferente. A busca por foguetes internacionais foi feita na modalidade de licitação para concorrência internacional, destinada a permitir a entrada de empresas internacionais diretamente, afirmam Silva et al. $(2021)^{91}$.

No período, segundo Silva et al. (2021) ${ }^{92}$ a equipe de licitações foi incumbida de licitar uma concorrência internacional para lançar o satélite, de forma a estabelecer uma rígida e burocrática documentação necessária (projeto básico, planejamento da contratação, e o mais trabalhoso, o processo de consultas de preços). E em aproximadamente um mês, ao receber o sinal de prontidão da engenharia do INPE foi divulgado a concorrência internacional no Diário Oficial do governo e em outros meios de comunicação. Por fim, no mês de dezembro, a autorização para realização de contratação do foguete foi concedida.

Para o lançamento, Moura et al. (2021) $)^{93}$ observa que o primeiro passo foi firmar o contrato 2 (dois) anos antes da concorrência internacional, o que deu tempo de contratar um veículo lançador e testá-lo no Amazonia-1. Nesta concorrência, destinada a realizar o contrato de lançamento, as empresas internacionais sejam dos americanos (Spacex), franceses (Arianespace S.A.), russos (Glav Kosmos) e indianos (Spaceflight) disputaram o lançamento do satélite, tendo de apresentar a documentação adequada de acordo com a Lei 8.666. No contexto, o Brasil solicitou que o veículo lançador e a base de lançamento a ser alugada, deveria conter condições, como: i) Atingir a órbita polar em 752,4 km de altitude; ii) Suportar o peso de, aproximadamente, 640 $\mathrm{kg}$; iv) Obter carregamento da bateria do satélite até o último minuto na plataforma de lançamento; v) Obter instalação própria na plataforma de lançamento para carregamento do tanque de hidrazina.; vi) Ter sólida confiabilidade de êxito em missões de lançamento.

As 4 (quatro) concorrentes, de início, foram inabilitadas porque não conseguiram apresentar a documentação necessária e; após 8 dias úteis como determinado pela Lei mencionada, as empresas apresentaram os documentos; e após a análise, duas empresas foram desclassificadas, Arianespace e Spacex. Por ser o maior volume de recursos já investido em um contrato pelo INPE, o lançamento foi estipulado inicialmente no teto de 130 milhões de reais; a empresa Spaceflight Industries norte-americana que representou o foguete indiano venceu a concorrência por atender os requisitos da missão, sendo contratada próximo ao valor de 97 milhões, e sob correção monetária até o lançamento, na estimativa de 110 milhões de reais, afirmam Silva et al. (2021) ${ }^{94}$.

A construção do satélite foi modelada e construída para ser compatível com tipologias variadas de veículos lançadores, tais como modelos DNEPR, EUROCXOT, Minotaur e VEJA, na Figura 16. O objetivo foi obter uma arquitetura flexível e robusta para adaptação a vários modelos de foguetes observados, aumentando as chances de encaixar-se no veículo lançador indiano. Após ser contratada, a réplica do Amazonia-1 foi preparada para testes de compatibilização, o que inclui validação das condições de vibrações do lançador Polar Satellite Launch Vehicle (PSLV), desenvolvido pela Indian Space Research Organisation (ISRO), argumenta Moura et al. (2021) ${ }^{95}$.

\footnotetext{
${ }^{90}$ Informação concedida no Canal Mensageiro Sideral por Salvador Nogueira, jornalista da ciência e sócio-fundador da Associação Aeroespacial Brasileira

${ }^{91}$ Informação concedida para o período na entrevista de Mário Saturno, vice-presidente da Comissão de licitações- INPE, ao canal Brasil com Ciência.

${ }^{92}$ Informação concedida para o período na entrevista de Horário H. Sawame, Presidente da Comissão de Licitações - INPE, ao canal Brasil com Ciência.

${ }^{93}$ Informação concedida para o período na entrevista de Marcos Chamon, Coordenador de Planejamento e Monitoramento - INPE, ao canal MundoGEO

${ }^{94}$ Informação concedida na entrevista de Horário H. Sawame, Presidente da Comissão de Licitações, e Mário Saturno, Vice-presidente da Comissão de licitações

- INPE, para o período ao canal Brasil com Ciência.

${ }^{95}$ Informação concedida para o período na entrevista de Marcos Chamon, Coordenador de Planejamento e Monitoramento - INPE, ao canal MundoGEO.
} 
Figura 16: Tipologia de veículos lançadores de referência para o Amazonia-1.

(a) DMEPR (Ucrânia)

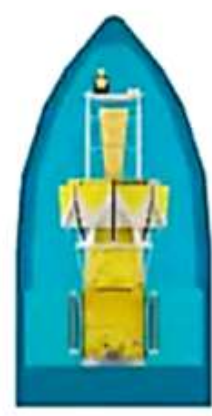

(b) EUROCXOT (Alemanha)

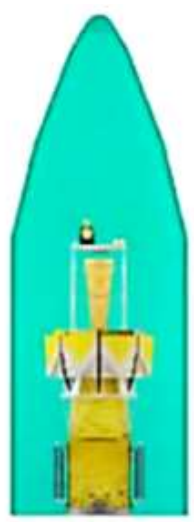

(c) Minotaur-C (EUA)

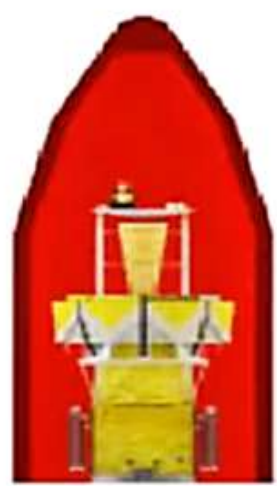

(d) VEJA (Europa)

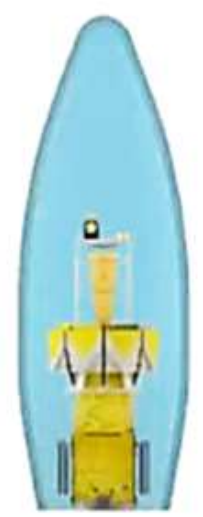

Fonte: INPE $(2021)^{96}$

Em 2020 no Brasil, Silva et al. (2021) ${ }^{97}$ afirma que foi realizado um conjunto de testes e validações dos subsistemas na área elétrica, térmica, de voo, de transporte e referente à campanha de lançamento. Estando concluído o teste de voo e o processo de validação para suportar vibrações, caminhou-se em rumo a finalização dos painéis solares. O prazo limite para o lançamento se encerrava em, aproximadamente, 1 (um) ano. Então pronto ao final de 2020, o satélite pesa 650kg e foi dividido em dois cubos no Brasil para agilizar o transporte para a Índia e organizado em 52 contêineres especiais com peso total de, aproximadamente, entre 20-26 toneladas. Embora esta divisão do satélite em partes fosse considerada uma escolha arriscada para se remontar num país estrangeiro, a tecnologia foi montada com êxito no Centro Espacial de Satish Dhawan no sudeste da Índia.

$\mathrm{Na}$ base de lançamento da Índia, depois do transporte 26 engenheiros se revezaram para verificar o funcionamento dos componentes tecnológicos para então instalar o artefato satelital no foguete. A Figura 17 a seguir ilustra que, primeiro, realizouse pontos de aterramento, e as verificações elétricas, pois o artefato estava armazenado por alguns dias. A integração do painel solar foi iniciada, os painéis solares foram retirados do container, e depois, integrados ao satélite, para que ao estarem dobrados, se retraiam e sejam abertos quando no espaço. Após isto, são executados os testes dinâmicos, de vibração e acústico; terminada essa etapa, o satélite foi vedado na capa MLI, afirmam Moura et al. (2021) ${ }^{98}$; Silva et al (2021) ${ }^{99}$.

\footnotetext{
${ }^{96}$ Captura de frame de vídeo 58:12 minutos. Acesso em 22 de dezembro de 2021, disponível em: https://www.youtube.com/watch?v=LUWDowkpLP8.

${ }^{97}$ Informação concedida no vídeo "Satélite Amazônia: a história não contada", do canal Brasil com Ciência para o período na entrevista de Heitor Patire Júnior, doutor em Engenharia Aeronáutica e Mecânica e Tecnologista do INPE.

${ }^{98}$ Informação concedida para o período na entrevista de Marcos Chamon, Coordenador de Planejamento e Monitoramento - INPE, ao canal MundoGEO.

${ }^{99}$ Informação concedida no vídeo "Satélite Amazônia: a história não contada", do canal Brasil com Ciência para o período na entrevista de Heitor Patire Júnior, doutor em Engenharia Aeronáutica e Mecânica e Tecnologista do INPE.
} 
Figura 17: Principais Fases no Pré-Lançamento do Satélite Amazonia-1.

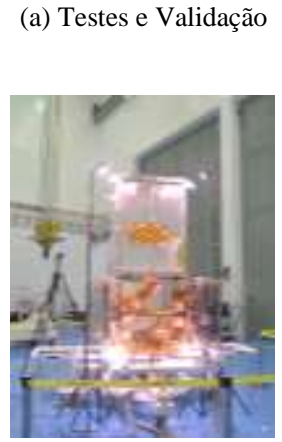

(b) Instalação

MLI - Multilayer

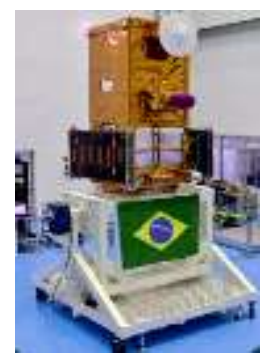

(c) Carregamento do

Taque da Hidrazina

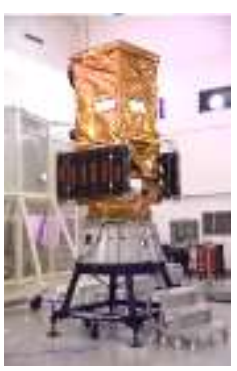

(d) Integração Sis. de Separação.

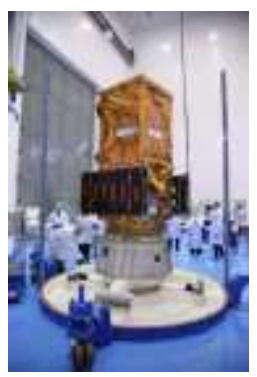

(e) Instalação na Coifa

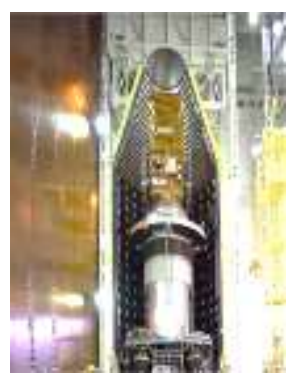

(f) Satélites

Instalados

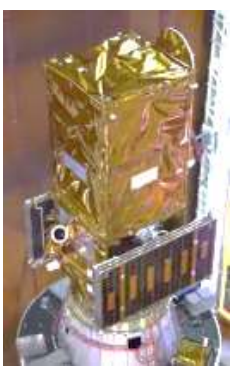

Fonte: Inpemct $(2021)^{100}$.

Entre as últimas operações realizadas pela equipe, estão o carregamento do tanque de hidrazina e a integração com o Sistema de Separação. Decorreu-se dias de testagem pela equipe brasileira, e confirmou-se o estado adequado da tecnologia e as condições ideais de voo para lançamento. Conforme na Figura 17 anterior, o satélite foi montado no veículo lançador, onde o artefato ao ser colocado dentro da coifa do foguete indiano PSLV, esteve protegido por este compartimento interno durante o voo, até se atingir o ambiente espacial. Para instalação no foguete, o satélite foi montado numa interface que contém uma base fixa no formato de círculo, em que é firmado por uma cinta de separação, e esta por sua vez, sela o acoplamento do satélite dentro do foguete, sendo um dos últimos estágios de montagem. Após o processo, na parte abaixo do Amazonia-1 dentro do foguete, foram instalados 18 pequenos satélites na estrutura do quarto estágio, Fourth Stage - PS4, afirmam Moura et al. (2021) ${ }^{101}$ e Silva et al $(2021)^{102}$.

Na missão PSLV-C51 em 28 de fevereiro de 2021, segundo Moura et al. (2021) ${ }^{103}$ lançou-se o Amazonia-1 por meio do foguete indiano PSLV, colocando-o em órbita 752,4 km de altura com erro de apenas 2 metros. Na Figura 18 a seguir, o veículo lançador PSLC-C51, dividiu-se em quatro estágios para atingir a órbita polar Sol-síncrona, é considerado de porte médio por obter o alcance de aproximadamente altitudes entre 600 e $900 \mathrm{~km}$, sob o motor configurado (sufixo G, CA, XL e 3S). Embora a configuração básica do foguete (PSLV-CA) quase foi suficiente em capacidade, o foguete PSLV-C51 é a variante "DL" do PSLV e que foi selecionado por suportar maior capacidade de transporte do carregamento, a exemplo de pequenos satélites a serem transportados como carga secundária, sendo possível por ser equipado com 2 (dois) boosters sólidos de cinta, isto é, dois foguetes reforçadores para aumentar o empuxo inicial do voo.

Segundo Moura et al. (2021) ${ }^{104}$ observa que a Figura 18 seguinte demonstra que o voo se iniciou com a ignição do motor principal e, na seguida se separaram boosters, de forma a separar o primeiro estágio na sequência, habilitando o segundo estágio. Neste momento, em pleno voo e inclinando-se para saída da atmosfera, abre-se a ponta do satélite, Playload Fairing, a coifa; e ao deixar o artefato satelital exposto, separa-se o segundo estágio, seguindo a sequência até habilitação do terceiro; e no quarto estágio, tendendo ao voo inclinado, alcançando próximo a exosfera; se separa a ignição de modo a executar a fase Cutoff, que é a separação do satélite para lançamento em órbita. No quarto estágio, foram executadas sequências programadas no foguete nas órbitas planejadas para ejetar o Satélite Amazonia-1 e, na altitude acima, lançar os 18 satélites co-passageiros ${ }^{105}$.

\footnotetext{
${ }^{100}$ Capturas de frames de vídeos. Acesso em 05 de dezembro de 2021, disponível em: https://www.youtube.com/watch?v=aPPdfDKp81o.

${ }^{101}$ Informação concedida na entrevista de Me. Adriana E. A. Corrêa, tecnologista do INPE e membro da Coordenação de Pesquisa, Desenvolvimento e Inovação (CDI), para o período ao canal MundoGEO.

${ }^{102}$ Informação concedida para o período na entrevista de Heitor Patire Júnior, doutor em Engenharia Aeronáutica e Mecânica e Tecnologista do INPE no vídeo "Satélite Amazônia: a história não contada", do canal Brasil com Ciência.

${ }^{103}$ Idem: Informação concedida na entrevista de Me. Adriana E. A. Corrêa ao canal MundoGEO.

${ }^{104}$ Informação concedida na entrevista de Me. Adriana E. A. Corrêa para o período ao canal MundoGEO.

${ }^{105}$ Segundo Isro (2021), foram 4 (quatro) do IN-SPACE e 14 do NSIL. Os quatorze satélites do NSIL são comerciais da Índia e dos EUA. Dos 4 (quatro) satélites do IN-SPACe, no total 3 (três) são UNITY stats projetados e construídos como um desenvolvimento conjunto pelo Jeppiaar Institute of Technology,
} 
Figura 18: Perfil de Voo do Veículo lançador (PSLV-C51) - Satélite Amazonia-1.

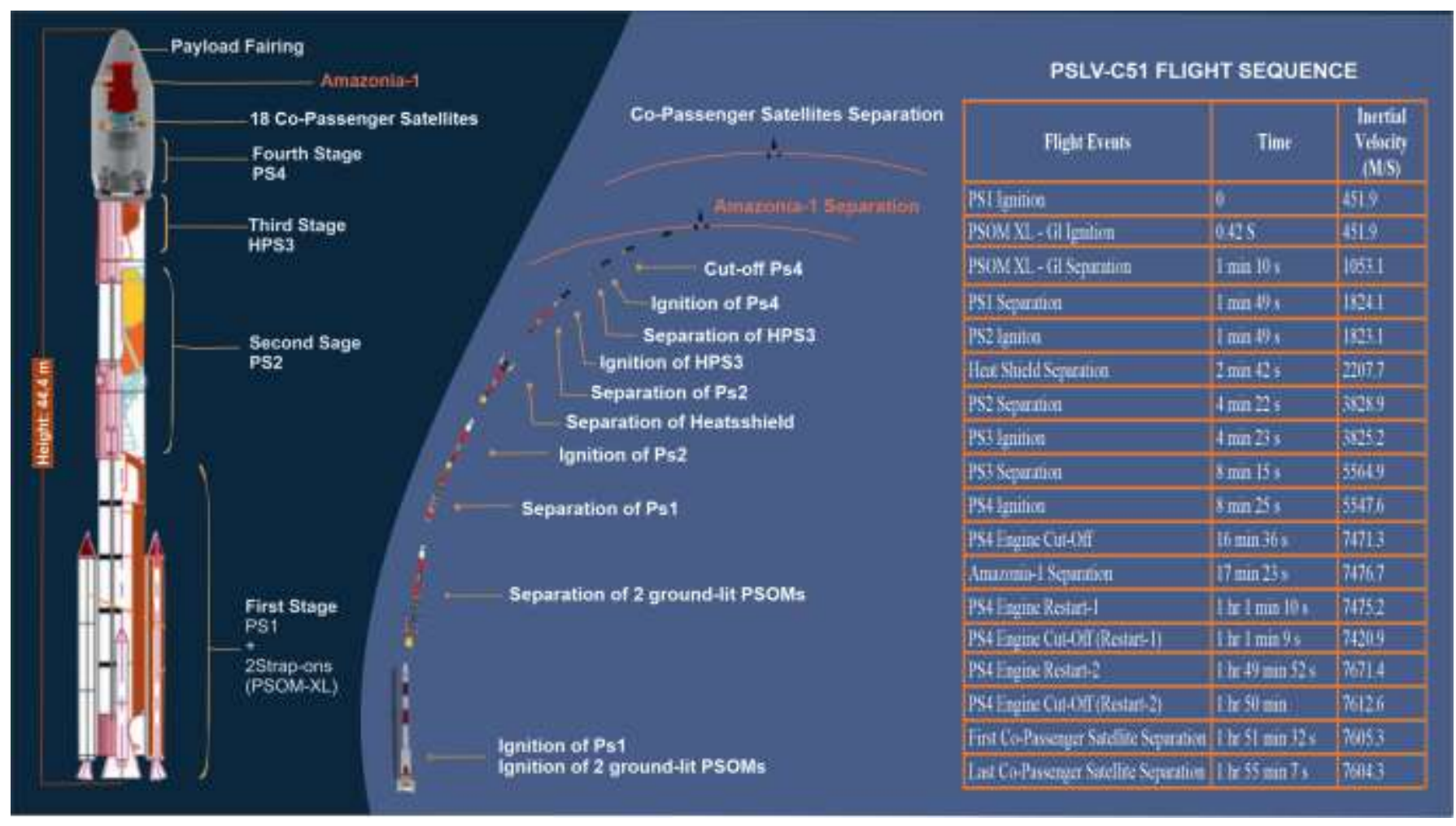

Fonte: Adaptada pelos autores $(2021)^{106 .}$

Embora a previsão de separação do Amazonia-1 foi 16 min $23 \mathrm{~m}$, demorou na prática 18 minutos para alcançar a exosfera. No momento em que foi lançado no ambiente espacial, os painéis solares foram abertos, e comandado pela base operacional no Brasil. Depois do lançamento, foi executado as fases de abertura do painel solar, estabilização da posição em relação a órbita, verificação dos sistemas e a ativação do módulo de prontidão. Após esses dois dias da fase de testes, obteve-se êxito oficial nos subsistemas satelitais (INPE, 2021) ${ }^{107}$.

Quando em março do mesmo ano, o artefato foi colocado em órbita nominal na fase de manobra e, após alguns meses, realizou-se o comissionamento da câmera WFI por uma banca de revisores, em que foi atestado a adequada presença radiométrica e geométrica nas imagens das duas passagens diurnas ${ }^{108}$. A partir disso, foi oficialmente declarado operante somente no mês de junho, sendo as imagens disponibilizadas para o público (INPE, 2021 $1^{109}$; Nardin, 2021).

$\operatorname{Nardin}^{110}$ (2021) analisa na Figura 19 a seguir, referente a fase de calibração e verificação do satélite, a fotografia da tela planificada de operação no lado esquerdo, demonstra como ocorre a coordenação do sensoriamento remoto no Centro de Recepção, Controle e Rastreio de Satélites, em São José dos Campos (SP). O software de monitoramento ATRON capta a localização em tempo real do satélite; e exibe na tela, uma linha pontilhada na vertical na órbita por onde passa, em segundos, o Satélite Amazonia-1, apontado pela seta na Figura 19 (a), na foto do lado esquerdo. E na tela de operação, os círculos que representam as visadas das antenas, que é o campo de visão das órbitas, em que as imagens foram captadas. No momento em

Sriperumbudur (JITsat), GHRaisoni College of Engineering, Nagpur (GHRCEsat) e Sri Shakti Institute of Engineering and Technology, Coimbatore (Sri Shakthi Sat) e um era Satish Dhawan Sat (SDSAT) do Space Kidz India. Disponível em: https://www.isro.gov.in/launcher/pslv-c51-Amazônia-1. Acesso em: 01/12/2021. 106 Elaborado com informação visual de Indian Space Research Organisation. Disponível em: < https://www.isro.gov.in/sites/default/files/pslvc51_Amazônia_01_-_brochure.pdf >. Acesso em: 01/11/2021.

${ }_{107}$ Acesso em 05 de dezembro de 2021, disponível em: https://www.gov.br/aeb/pt-br/assuntos/noticias/amazonia-1-e-lancado-com-sucesso-e-ja-esta-em-orbita. ${ }^{108}$ Na primeira janela de passagem, na direção leste, foi captada nas estações terrenas do INPE em Cuiabá e Cachoeira Paulista; o segundo trecho do imageamento foi captado na estação terrena do INPE em Cuiabá, na direção a oeste. Além disso, de outros ajustes feitos na configuração do sensor remoto com vistas a otimização da qualidade das imagens (INPE, 2021). Disponível em: http://www.inpe.br/institucional/sobre_inpe/instalacoes.php. Acesso em: 01/12/2021.

${ }^{109}$ Disponível em: https://www.gov.br/aeb/pt-br/assuntos/noticias/amazonia-1-e-lancado-com-sucesso-e-ja-esta-em-orbita. Acesso em: 01/12/2021.

${ }^{110}$ Informação concedida na entrevista de Clézio Marcos de Nardin, o diretor do Instituto Nacional de Pesquisas Espaciais (INPE), no período ao canal Inpemct. 
que o satélite atingir a altitude da órbita ideal, de modo a capturar as primeiras imagens do satélite, a telemetria é recebida no centro de recepção, dispondo de imagens como na Figura 19 (b), na foto do lado direito. Para obter melhor visualização da região amazônica, foram sincronizados o Amazonia-1 junto a 5 (cinco) satélites simultâneos presentes que obtinham ângulos complementares de passagem.

Figura 19: Fotos da tela de operação e demonstração de imagem capturada.

(a) Tela do Op. Software ATRON em Tempo Real

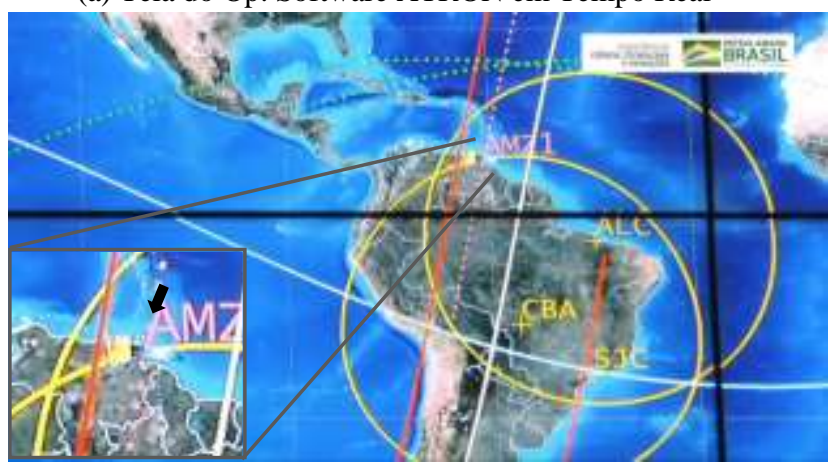

(b) Primeiras Imagens (Amazônia, Manuripi-Heath na Bolívia)

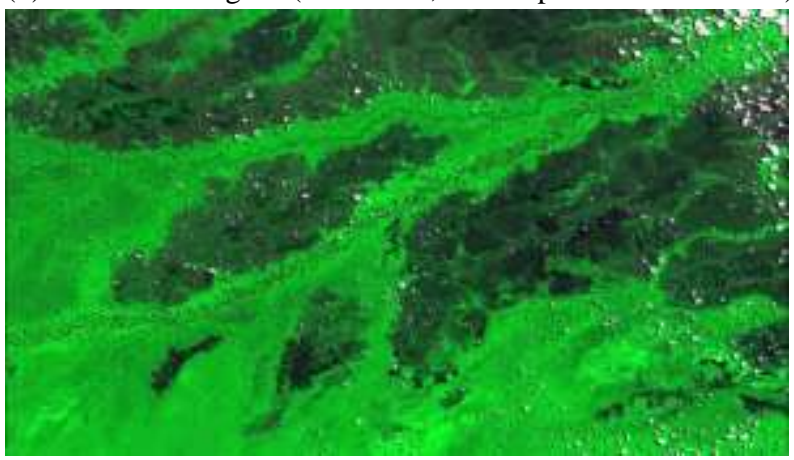

Fonte: (a) TvBrasilGov $(2021)^{111}$, (b) INPE (2021) ${ }^{112}$.

A experiência de desenvolvimento (planejamento e implementação) ${ }^{113}$ do Amazonia-1 executada pelo INPE obteve avanços tecnológicos, a saber: i) A engenharia da Plataforma Multimissão (PMM) cujo o pacote tecnológico obtém uma arquitetura compacta que permite o fornecimento de sobrevida ao satélite no espaço; ii) Subsistema de Propulsão otimizado para controle de altitude e de órbita foi estabilizado por rotação em três eixos e fornece um controle preciso, sendo de origem brasileira na maior parte aumentando a autossuficiência produtiva em tal quesito; iii) Os mecanismos de painéis solares possibilitam a abertura eficaz do painel; iv) O desenvolvimento do Diamond-Like Carbon (DLC), que é um lubrificante sólido para uso nas estruturas espaciais e; v) Subsistema de câmera WFI otimizado para imageamento do uso e cobertura do solo e florestas em larga escala; vi) e a capacidade de produção de satélites no prazo estimado de 3 anos (Silva et al. 2021 ${ }^{114}$; Moura et al. 2021 ${ }^{115}$ ).

\section{Considerações Finais}

A Missão Amazônia atingiu seus objetivos de formação de competências para qualificação da indústria nacional, execução brasileira completa do ciclo tecnológico espacial, inclusive na fase de sensoriamento remoto, bem como fortaleceu a proteção ambiental a floresta amazônica, a região com maior biodiversidade do planeta. Do contexto do projeto ao lançamento, os atrasos do Satélite Amazonia-1 foram explicados pelas mudanças de prioridade, demora nos contratos com a iniciativa privada, déficit de recursos financeiros, decréscimo de contratação de funcionários e de equipamentos, entre outros problemas identificados. Portanto, há de se descartar que um dos maiores ganhos da Missão Amazônia foi alavancar a educação espacial brasileira referindo-se à transferência tecnológica para outro patamar técnico-científico no país. Foi obtido experiências significativas e com êxito na formulação conceitual, implementação satelital e no lançamento (na dificuldade de plena pandemia) e entre outros aprendizados, como montagem do artefato em um país estrangeiro.

Portanto, historicamente obteve-se ganhos imateriais, que se referem a educação espacial obtida, como: a) A consolidação e ganho inédito de conhecimentos tecnológicos de engenharia, e em diversos campos científicos da cadeia

\footnotetext{
${ }^{111}$ Captura de frame de vídeo. Acesso em 15 de novembro de 2021, disponível em: https://www.youtube.com/watch?v=I-HCdM3853k.

${ }_{112}$ Primeiras imagens capturadas pelo Amazonia 1. Acesso em 13 de janeiro de 2022, disponível em: http://www.inpe.br/noticias/noticia.php?Cod_Noticia=5725.

${ }^{113}$ Segundo Chamon (2021), há poucas peças das cópias foram utilizadas, contabilizando um valor agregado de 80 milhões em partes separadas que representam

$70 \%$ de uma nova plataforma multimissão, a ser construída (Informação verbal).

${ }^{114}$ Informação concedida na entrevista de Me. Adriana E. A. Corrêa para o período ao canal MundoGEO.

${ }^{115}$ Informação concedida para o período na entrevista de Marcos Chamon, Coordenador de Planejamento e Monitoramento - INPE, ao canal MundoGEO.
} 
produtiva, como de lançamento para satélites de alta complexidade e de médio porte, aprimorando tecnologias espaciais brasileiras, de forma a consolidar a maturidade no desenvolvimento de satélites; b) Promoção da educação espacial pela transferência do conhecimento tecnológico a 10 empresas brasileiras contratadas; c) A execução da cadeia produtiva completa no segmento de espaço e solo, consolidando a soberania nacional, no sentido em que há autonomia do desenvolvimento de satélites estabilizado em três eixos e; d) A qualificação dos métodos de desenvolvimento satelital empreendido e de suas funcionalidades satelitais; e) O fomento à indústria espacial brasileira, de forma a empregar e valorizar cientistas brasileiros capacitados em produto de alto valor agregado (alta tecnologia).

São ativos intelectuais os conhecimentos adquiridos na forma da integração de equipes altamente capacitadas e de empresas participantes do projeto. Estes conhecimentos tecnológicos desenvolvidos a partir desta iniciativa satelital são conteúdos estratégicos e sensíveis que devem ser repassados, aprimorados e protegidos para que não se percam e gerar maior qualificação de cientistas e tecnologistas brasileiros nas universidades e instituições de ensino, pesquisa e extensão, tendo em vista, fomentar o setor espacial.

Assim sendo, o Satélite Amazonia-1 é um ativo intelectual produtivo e estratégico que contribuiu para desenvolver o Setor Espacial Brasileiro. Sua formulação conceitual e implementação satelital promoveu experiências educacionais para aprendizado das equipes e empresas envolvidas, bem como estimulou o aprimoramento tecnológico espacial da indústria espacial brasileira. Assim, presta uma contribuição relevante, ao disseminar este conhecimento pelo aprendizado obtido, desde projetos de transferência tecnológica, a demais experiências vivenciadas. Deste modo, a educação espacial brasileira foi fortalecida porque demonstrou em termos práticos que o conhecimento tecnológico e o trabalho conjunto transformam missões em satélites, estudantes em pesquisadores, desafios em resultados, o que fomenta o desenvolvimento socioeconômico brasileiro.

Para trabalhos futuros sugerimos duas pesquisas. A primeira deve ampliar a busca e a análise referente aos conteúdos videográficos sobre o Amazonia-1, de forma a documentá-los amplamente e efetivar a avaliação de sua informação; demanda observada no Mapeamento Sistemático (MS). A segunda proposta é desenvolver um algoritmo de inteligência artificial, Deep learning, capaz de identificação e aprendizado dos focos de desmatamento e queimadas a partir de imagens do satélite Amazonia1 e de outros satélites.

\section{Agradecimentos}

Aos Instituto Federal Goiano de Iporá e Instituto Nacional de Pesquisas Espaciais (INPE).

\section{Referências}

Amado, J. (1997). A culpa nossa de cada dia: ética e história oral. Projeto História: Revista do Programa de Estudos Pós-Graduados de História, 15.

Antunes, E. V. (2016). A evolução histórica do Programa Espacial Brasileiro. Seminário Nacional de História da Ciência e da Tecnologia, v. 15.

Bogossian, O. L, Epiphanio, J. C, Shimabukuro, Y. E, \& Rudorff. B. F. T. (1995). Avaliação da nova concepção do satélite de sensoriamento remoto para aplicação de monitoramento ambiental. Silo José dos Campos, p. 23.

Brasil (2016). Ministério da Saúde. Conselho Nacional de Saúde. Resolução no 510, de 7 de abril de 2016. Trata sobre as diretrizes e normas regulamentadoras de pesquisa em ciências humanas e sociais. Diário Oficial da União, Brasília, DF. Disponível em: http://conselho.saude.gov.br/resolucoes/2016/Reso510.pdf.

Brasil. (1994). Política Nacional de Acesso a Informações. Decreto nº 1.332, de 8 de dezembro de 1994. http://www.planalto.gov.br/ccivil_03/_ato20112014/2011/lei/112527.htm.

Breternitz, V. J, \& Silva, A. R. (2021). Amazônia no espaço: Satélite de observação da Terra totalmente construído no Brasil é colocado em órbita. Entrevista concedida a Yuri Vasconcelos. Revista Pesquisa FAPESP, São Paulo, 2021. https://revistapesquisa.fapesp.br/Amazônia-no-espaco/.

Bringhenti, L. S. M, Ambrosio, A. M, \& Santos, W. A. (2020). Uma metodologia para refinar os requisitos nas fases preliminares do projeto de sistemas espaciais considerando análises de risco e teste. $11^{\circ}$ Workshop em Engenharia e Tecnologia Espaciais.

Bussu, G. (2008) Materials and processes for space. IAASS Quality Assurance Course. European Space Agency-ESTEC. http://www.las.inpe.br/ perondi/11.11.2008/QA_Course_M\&P_2008_INPE.pdf. 
Câmara, G. (2012). INPE quer nacionalizar observação da Terra. Entrevista concedida à Folha de SP. Revista InfoGEO, MundoGEO, 2012. https://mundogeo.com/2006/03/01/INPE-quer-nacionalizar-observacao-da-terra-2/.

Castro Neto, J. C. (2021). Câmeras aumentam alcance de imagens de satélite. Entrevista concedida a Assessoria de Comunicação do IFSC. Agência USP de Notícias, 2016. http://www.usp.br/agen/?p=227084.

Costa Filho, E. de J. (2006). A dinâmica da cooperação espacial sul-sul: o caso do programa CBERS (China-Brazil earth resources satelite).

Costa, J. R. V. (2002). Brasil no espaço. Astronomia no Zênite. https://www.zenite.nu/brasil-no-espaco

Epiphanio, J. C. N. (2003). Satélites de Sensoriamento Remoto. In: Moraes, Elisabete Caria; Ávila, João. VI Curso de Uso de Sensoriamento Remoto no Estudo do Meio Ambiente. São José dos Campos: INPE.

Escada, M. I. S. (2008). Monitoramento da Cobertura Florestal da Amazônia por Satélites. INPE, Coordenação Geral de Observação da Terra, São José dos Campos.

Francisco, M. F. M. (2003). Sistemas computacionais em aplicações espaciais. São José dos Campos: INPE. 17 p. (INPE-9604-PUD/125). http://urlib.net/ibi/sid.inpe.br/jeferson/2003/10.13.15.25.

Galvão, R. (2021). Contrato para lançar satélite na Índia foi firmado em 2018. Entrevista concedida à Daniel Giovanaz e Poliana Dallabrida. Revista Brasil de Fato, São Paulo, 2021. https://www.brasildefato.com.br/2021/03/02/contrato-para-lancar-satelite-na-india-foi-firmado-em-2018.

Genaro, A. F. S. Silva, A. R. da. Silva, C. M. Z. \& Santos, M. A. D. (2021). Ciência Transformando Vidas - O Satélite Amazonia 1. https://www.youtube.com/watch?v=aPPdfDKp810.

Inácio, B. V. M., \& Pin, M. L. F. (2020, November). Desenvolvimento de uma Plataforma Multi-Missão (PMM) para lançamento de uma sonda estratosférica. In: $11^{\circ}$ Congresso de iniciação científica e tecnológica do IFSP.

INPE (2018). Documentação: AMAZÔNIA1 SATELLITE - Amazônia 1 AWFI Subsystem Specification. A823600-SPC-001/02.

Johnson-freese, J. (2007). Space as a strategic asset. New York: Columbia University Press. 304 p.

Junior, E. M (2013). Calibração da geometria interna das imagens do sensor AWFI/AMAZONIA-1. Anais XVI Simpósio Brasileiro de Sensoriamento Remoto SBSR. PR, Foz do Iguaçu, INPE.

Kaufmann, P; \& Silva, A. R. (2016). Um satélite brasileiro: Amazonia 1 desenvolvido no país vai monitorar recursos naturais e ajudar no combate ao desmatamento. Entrevista concedida a Yuri Vasconcelos. Revista Pesquisa FAPESP, São Paulo, Edição 239, jan. 2016. https://revistapesquisa.fapesp.br/umsatelite-brasileiro/.

Ley, W., Wittmann, K., \& Hallmann, W. (2009). Manual de tecnologia espacial - Handbook of Space Technology (Vol. 22). First edition, John Wiley \& Filhos.

Moura, C. Corrêa, A. E. A. Chamon, M. A. \& Almeida, C. (2021). Construção e Lançamento do Satélite Amazonia 1 [arquivo de vídeo]. Youtube. Disponível em: https://www.youtube.com/watch?v=LUWDowkpLP8.

Nardin, C. M. de. (2021). INPE apresenta as primeiras imagens de teste do satélite Amazonia 1 [arquivo de vídeo]. Disponível em: com/watch?v=H3SS7yBhxus

NASA. (2007). Systems Engineering Handbook. NASA Headquarters.

Nogueira, S. \& Barbosa, C. (2021). INPE divulga primeiras imagens do satélite brasileiro Amazônia-1. https://www.com/watch?v=OSkMXqKgurc

Orlando, V. A. L. C. I. R., \& Kuga, H. K. (2007). Os Satélites SCD1 e SCD2 da Missão Espacial Completa Brasileira-MECB. Chapter of book. In: A Conquista do Espaço-Do Sputnik à Missão Centenário, 151-176.

Pereira, G. R. (2008). Política e Desenvolvimento Tecnológico no Setor Espacial. Doctoral dissertation, Tese de doutoramento no Departamento de Política Científica e Tecnológica da UNICAMP.

Petersen, K., Feldt, R., Mujtaba, S., \& Mattsson, M. (2008). Estudos de mapeamento sistemático em engenharia de software. In: 12th International Conference on Evaluation and Assessment in Software Engineering (EASE) 12 (pp. 1-10).

Pontes, M. (2021). Ministro Marcos Pontes sobre satélite Amazônia-1: Expectativas enormes. Youtube. https://www.youtube.com/watch?v=X17Rf_EJqcw.

Reis, N. T. O., Garcia, N. M. D., Souza, P. N. D., \& Baldessar, P. S. (2008). Análise da dinâmica de rotação de um satélite artificial: uma oficina pedagógica em educação espacial. Revista Brasileira de Ensino de Física, 30, 1401-1.

Rudorff, B. F. T, Epiphanio, J. C, Shimabukuro, Y. E, Krug, T, \& Carvalho, H. C. (1996). Application of the Brazilian Remote Sensing Satellite (SSR) to Monitor the Amazon Region. International Archives of Photogrammetry and Remote Sensing, 31, 599-601. http://mtcm12.sid.INPE.br/rep/6qtX3pFwXQZ3r59YD6/GPhpG.

Santos, R. (2010). Estratégia de Formação, Capacitação, Treinamento Operacional e Retenção de Recursos Humanos. In: Brasil. Presidência da República. Secretaria de Assuntos Estratégicos. Desafios do Programa Espacial Brasileiro. Brasília, DF; SAE, p. 253-258.

Santos; L. Correa, A. E. \& Quintanilha, C. E. (2021). Uma breve história dos satélites brasileiros até o AMAZÔNIA 1 https://www.com/watch?v=sMBr_jQ9FHg. Sausen, T. M. (2009). Educação espacial na América Latina e a posição do Brasil no contexto regional. Parcerias estratégicas, 4(7), 151-164. 
Research, Society and Development, v. 11, n. 2, e29011225894, 2022

(CC BY 4.0) | ISSN 2525-3409 | DOI: http://dx.doi.org/10.33448/rsd-v11i2.25894

Scaduto, L. C. N, Carvalho, E. G, \& Santos, A. R. (2019). A câmera Advanced Wide Field Imaging (AWFI) para o satélite brasileiro Amazonia 1. Na Conferência Internacional sobre Óptica Espacial -ICSO 2010. 10565, 105655. Sociedade Internacional de Óptica e Fotônica.

Scaduto, et al. (2010). The Advanced Wide Field Imaging camera (AWFI) for the Amazonia 1 Brazilian satellite. 10.1117/12.2552753.

Scorsolini-Comin, F. (2021). Projeto de pesquisa em ciências da saúde: guia prático para estudantes. Editora Vozes.

Silva, A. R, Neto, J. R, Almeida, C, \& Junior, C. S. (2019). Por dentro do Amazonia-1, primeiro satélite de monitoramento 100\% brasileiro. Entrevista concedida a Kevin Damasio e Miguel Vilela. National Geographic, https://www.nationalgeographicbrasil.com/espaco/2019/11/por-dentro-do-Amazonia-1-primeirosatelite-de-monitoramento-100-brasileiro.

Silva, A. R. da. (2021). Brasil vai lançar o satélite Amazonia-1 - Entenda como ele funciona! https://www.youtube.com/watch?v=PENLOWufGtg.

Silva, A. R. da. (2021). Satélite Amazonia-1 no LIT/INPE: simulação de 100 horas em órbita e fechamento dos painéis laterais [arquivo de vídeo]. Disponível em: https://www.com/watch?v=BZu-fTS7FnQ.

Silva, A. R. da.; Júnior, H. P.; Sawame, H. H.; \& Saturno, M. (2021). Satélite Amazônia: a história não contada [arquivo de vídeo]. Disponível em: https://www.com/watch?v=dcR0bhGHKiU.

Silva, D. F. D, Muraoka, I., \& Garcia, E. C (2014). Concepção do projeto de controle térmico do satélite Amazonia-1. Journal of Aerospace Technology and Management, 6, 169-176.

Silva, N. M. V., Santos, C. V. M., \& Rhodes, C. D. A. A. (2014). Do vídeo para o texto escrito: Implicações para a análise da interação. Psicologia em Revista 20(3), 513-528.

Silva, F. J. L. T., Rocha, D. F., \& Aquino, C. M. S. (2016). Geografia, geotecnologias e as novas tendências da geoinformação: indicação de estudos realizados na região Nordeste. InterEspaço: Revista de Geografia e Interdisciplinaridade, 176-197.

Venticinque, G. (2021). Painel solar do Satélite Amazonia-1 é testado em Laboratório (LIT) do INPE https://www.com/watch?v=Y7-esIOEliw

Viegas, L., \& dos Santos, J. C. (2020). As ações governamentais brasileiras no fomento a Ciência, Tecnologia e Inovação-CT\&I estão buscando autonomia tecnológica para o país? Revista Brasileira de Estudos Estratégicos.

Vinci, E., \& Saotome, O. (2009). Arquitetura de Hardware do Computador de Bordo para o Satélite Universitário ITASAT e Confiabilidade. In: Proceedings of the 2009 Brazilian Symposium on Aerospace Engineering and Applications (pp. 59028-59030).

Wertz, J. R, \& Larson, W. J. (2011). Space Mission Analysis and Design. Third Edition. Space technology library. Microcosm. 